Article

\title{
A Soft Systems Approach to Knowledge Worker Productivity-Analysis of the Problem Situation
}

\author{
Helga Guðrún Óskarsdóttir (D) and Guðmundur Valur Oddsson * \\ Department of Industrial Engineering, University of Iceland, Reykjavik 101, Iceland; hgo2@hi.is \\ * Correspondence: gvo@hi.is; Tel.: +354-5254335
}

Academic Editor: Ralf Fendel

Received: 8 March 2017; Accepted: 21 July 2017; Published: 1 August 2017

\begin{abstract}
Low knowledge worker productivity is an important problem that needs to be addressed. Current research addressing this problem is fragmented and deals with different isolated elements of the problem. There is a need for a holistic approach to knowledge worker productivity. This paper takes the first steps of a holistic approach to knowledge worker productivity by using soft systems methodology to describe the problem situation. The main challenge of this research was the abstraction of the results from two literature reviews into simple rich pictures and specific root definitions to identify the fundamentals of knowledge worker productivity. The problem situation was explored from the perspective of two problem owners, the organization and the individual knowledge worker. The rich picture from the perspective of the organization highlighted that the organization must communicate what they perceive as value and create a work environment that promotes collaboration, encourages knowledge sharing, motivates and fulfills the needs of their knowledge workers. The rich picture from the perspective of the individual knowledge worker highlighted the fact that knowledge workers need to manage their personal resources, be effective and efficient to maximize their own productivity. This paper attempts to integrate these two perspectives into a holistic view.
\end{abstract}

Keywords: soft systems methodology; rich picture; personal resources; energy management; organization; work environment; knowledge worker productivity; management; knowledge management; retaining knowledge workers

JEL Classification: D03; D20

\section{Introduction}

Drucker (1999) stated that the most valuable asset of a 20th century organization was its production equipment and predicted that the most valuable asset of a 21st century organization would be its knowledge workers and their productivity. He was right: knowledge workers can be the key to an organization's competitive advantage (Jayasingam and Yong 2013). Knowledge workers use their expertise, education or experience to create, share or apply knowledge in their job, so that they can contribute to their organizations. Their work is non-routine, creative and requires intelligence to solve new problems every day, make decisions and fulfill the requirements of customers and other stakeholders. The number of knowledge workers has increased due to trends such as new sectors of knowledge production within the economy (Scarbrough 1999), new technology and automation that reduce the need for manual work (Gunasekaran et al. 1994) and a more service-oriented market.

Low knowledge worker productivity is an important problem that needs to be addressed. Organizations are dependent on the value produced by knowledge workers. They need to be able to affect the productivity of knowledge workers to run and improve their business. In 1959, 
Peter F. Drucker drew attention to the fact that the discipline of personnel management wasn't equipped to handle the challenges people face doing knowledge work (Drucker 1959). Personnel management practices were based on unskilled or semiskilled machine work (Drucker 1959). How knowledge worker productivity is approached, therefore, needs to be revolutionized like Frederick Taylor revolutionized how manual worker productivity was approached with scientific management. Unfortunately the methods, such as scientific management, used in the 20th century to increase the productivity of manual work are not directly relevant to knowledge workers (Drucker 1966). Scientific management assimilated the knowledge of the worker into the organizational process (Paton 2013). This was possible because manual workers use their skills to execute routine tasks, which do not require constant problem solving and decision making. On the other hand, the knowledge worker is only valuable if he owns his knowledge assets (Paton 2013). To contribute he needs to pervade data and information with decision and reflection, which makes the knowledge created inseparable from the individual (Seethamraju 2000). The knowledge worker must be able to act autonomously and manage himself to unlock the value of his knowledge (Paton 2013; Mandt 1978). Since his knowledge cannot be assimilated into the organizational process the productivity of the worker needs to be directed to create value for the organization. Value is subjective, so the organization needs to communicate what is perceived as value to them.

Even though many breakthroughs have been made on the subject of knowledge worker productivity current research addressing this problem is fragmented and deals with different isolated elements of the problem. There is a need for a holistic approach to knowledge worker productivity to find applicable methods to manage and improve it. This research is a first step of many to tackle the knowledge worker productivity challenge with a holistic approach using systems. This paper describes the problem situation of low knowledge worker productivity by drawing conclusions from data gathered in two literature reviews and defines relevant systems using soft systems methodology. Soft systems methodology was created as a response to the complexity of everyday problems that were hard to fit into mathematically expressed general theory of systems (Checkland 1993). Checkland (1993) found that one reason for the complexity of these everyday problems was because each stakeholder had different views of the problem and therefore what constitutes the system. The soft systems approach therefore identifies problem owners that give the point of view of the system. Knowledge worker productivity is a good example of such a multi-dimensional problem.

Taylor (1911) said "in the past the man has been first; in the future the system must be first". Knowledge worker productivity is in the same state now as manual worker productivity was in the year 1900 (Drucker 1999). All eyes are on the individual knowledge worker but not the systems that he functions in. Even though the knowledge worker needs to have autonomy to manage himself he is confined and influenced by the systems in his world. There is a need to define these systems and analyze how they affect the knowledge worker. The soft systems process consists of seven stages which are the problem situation, unstructured; the problem situation, expressed; root definitions of relevant systems; conceptual models; comparison of conceptual models with the problem situation; feasible desirable changes; action to improve problem situation (Checkland 1993). This research executes the first three stages by using some of the tools Checkland (1993), Checkland and Scholes (1999) provide such as the three analyses, rich pictures, CATWOE and root definitions. These tools are discussed in detail in the method section. This research hopes that by exploring the problem and defining the relevant systems of knowledge worker productivity using soft systems methodology will give insight and provide a stepping stone to a holistic approach to knowledge worker productivity.

Current research can be split into two factions: (i) the faction of those who emphasize knowledge management, the process of codifying knowledge into external systems and handling the data and information. It assumes that knowledge worker productivity can be improved by fulfilling information needs, minimizing information overload and making knowledge sharing easier; and (ii) the faction that focuses on retaining knowledge workers through increased motivation, work-engagement and commitment to the organization. That faction assumes that knowledge cannot be effectively codified 
and that the best way to retain organizational knowledge and improve knowledge worker productivity is by investing in the workers. Other popular subjects include managing knowledge workers, health problems of knowledge workers and teamwork. There is a need to combine the findings of current research, identify the elements that affect knowledge worker productivity and explore how they work together by creating a holistic view.

This paper explores the problem situation of low knowledge worker productivity by abstracting the results of literature reviews into simple rich pictures and specific root definitions of relevant systems. To gain an understanding of the problem situation literature reviews of knowledge worker productivity challenges were executed, one of academic papers and another of a proxy for industry. The literature reviews identified four main knowledge worker productivity challenges targeted by current research and eight main challenges targeted by industry. This information was used in a soft systems approach to analyze the problem situation and define relevant systems. The soft systems approach identified two problem owners, the organization and the individual knowledge worker, and resulted in two rich pictures of the problem situation and two root definitions for relevant systems. This paper also explores the interactions between these two systems by creating an abstract holistic view of knowledge worker productivity.

\section{Methods}

This research used the seven stage model from the soft systems methodology described by Checkland and Scholes (1990) and executed the first three stages to analyze the problem situation and define relevant systems. Table 1 shows an overview of the execution of the first three stages.

Table 1. An overview of the execution of the first three stages of the soft systems approach.

\begin{tabular}{llll}
\hline \multicolumn{1}{c}{ Execution Step } & \multicolumn{1}{c}{ Description } & \multicolumn{1}{c}{ Results of the Execution } & Section \\
\hline & $\begin{array}{l}\text { To get an overview of the knowledge } \\
\text { worker productivity challenge two } \\
\text { literature reviews were executed. A } \\
\text { literature review of knowledge worker } \\
\text { productivity challenges on the Web of } \\
\begin{array}{l}\text { Stage 1: The } \\
\text { problem situation and a literature review of } \\
\text { unstructured } \\
\text { personal productivity self-help books as } \\
\text { a proxy for industry. }\end{array}\end{array}$ & $\begin{array}{l}\text { Identified four main knowledge } \\
\text { worker productivity challenges } \\
\text { targeted by current research and } \\
\text { eight main challenges targeted by } \\
\text { industry }\end{array}$ & 2.1 .2$. \\
& $\begin{array}{l}\text { The inferences made from the literature } \\
\text { reviews were used to identify problem } \\
\text { owners, execute an analysis of the } \\
\text { intervention and draw rich pictures of } \\
\text { the problem situation. }\end{array}$ & $\begin{array}{l}\text { Two problem owners identified, } \\
\text { the organization and the } \\
\text { individual knowledge worker. } \\
\text { A rich picture was drawn for each } \\
\text { problem owner. }\end{array}$ & 2.3 \\
$\begin{array}{l}\text { Stage 2: The } \\
\text { problem situation, } \\
\text { expressed }\end{array}$ & $\begin{array}{l}\text { A CATWOE analysis was performed to } \\
\text { help formulate a root definition of } \\
\text { relevant systems. }\end{array}$ & $\begin{array}{l}\text { Two root definitions were } \\
\text { formulated, one for each problem } \\
\text { owner. }\end{array}$ & 2.3 \\
\hline $\begin{array}{l}\text { Stage 3: Root } \\
\text { definitions of } \\
\text { relevant systems }\end{array}$ & & & 2.3 \\
\hline
\end{tabular}

The following sections describe the methods used for each of the stages in the table above.

\subsection{Literature Review-Academic}

A literature review search was executed on the Web of Science in June 2016. It searched for papers with a topic that touched on a knowledge, information or white-collar worker productivity problem or challenge. The search resulted in fifty-nine papers from which forty-five were selected by title review. If the title indicated any relevance to the topic it was chosen. The search term can be found in Table 2. 
Table 2. Literature review search term.

\begin{tabular}{|c|c|}
\hline Search term & Timespan \\
\hline 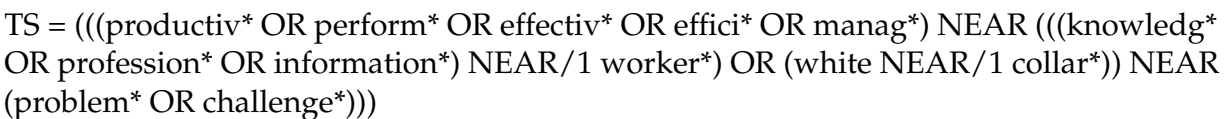 & All years \\
\hline
\end{tabular}

Six papers were not available, so thirty-nine papers were read to extract information about what challenges they were targeting and proposing solutions to. The main subjects of each paper were then categorized into themes and main challenges identified from those themes.

\subsection{Literature Review-Industry}

The literature review used personal productivity self-help books as a proxy for industry and was designed using Kitchenham (2004) guidelines for performing systematic literature reviews in software engineering. Personal productivity self-help books were chosen as a proxy for industry since they are mostly written by consultants working with organizations and individual knowledge workers with industry experience. Of the forty popular personal productivity self-help books read in this literature review, $63 \%$ of the authors are consultants and $19 \%$ of authors are writing from personal experience. Only $17 \%$ of the authors come from the academic world. The authors had on average 18 years of experience working with productivity issues and $50 \%$ of the authors had founded companies around their ideas. The objective of the literature review was to get insight into the productivity challenges of the individual knowledge worker.

To find popular personal productivity books for the literature review the researchers developed a software program, ReviewSearchHelper (Óskarsdóttir 2013, 2014), to search and fetch information systematically from the online retailer Amazon.com. It used the Amazon Product Advertising API to search for books on Amazon.com (Óskarsdóttir 2014). The ReviewSearchHelper traverses through the hierarchy of Amazon.com book categories for each keyword and extracts information about the books in included categories (Óskarsdóttir 2014). For more detailed information about this software and the codebase itself see references (Óskarsdóttir 2013, 2014).

The search was performed in September 2013. The keywords used in the search were: productivity, personal productivity, effective, effectiveness, efficiency and knowledge worker productivity. An unrestricted book search gave 41,097 book results. This indicated that the search needed to be limited. This was done by excluding book categories from the search. The list of book categories from Amazon.com was manually reviewed using an exclusion criteria checklist that can be seen in Table 3 .

Table 3. Book category exclusion criteria.

Exclude if results are:

- About a specific industry or roles, dependent on tools or software, religion specific, about historical events, about job search or hiring, about managing or leading people or about organizations not individuals

A restricted book search was then executed only in the selected book categories for each keyword, which resulted in 1903 book results. A selection criteria checklist with an emphasis on the productivity of the individual knowledge worker was used to manually select 272 relevant books from the 1903 unique book results. Table 4 shows the book selection criteria. 
Table 4. Book selection criteria.

\begin{tabular}{ll}
\hline \multicolumn{1}{c}{ Include if: } \\
\hline - $\quad \begin{array}{l}\text { Focus on improving readers personal productivity (e.g., improving creativity, discretion, performance } \\
\text { measures, incentives, technology, defining tasks and results, goals, efficiency, effectiveness, defining } \\
\text { quality, focus, autonomy, accountability and continuous learning) }\end{array}$ \\
\hline \begin{tabular}{l}
\multicolumn{1}{c}{ Exclude if: } \\
\hline -
\end{tabular}$\quad \begin{array}{l}\text { About organizational productivity, team productivity, improving productivity of others through } \\
\text { fulfillment or job hunting }\end{array}$ \\
- $\begin{array}{l}\text { Industry, religion or tool specific } \\
\text { Specific target group e.g., teenagers or women only }\end{array}$ \\
\hline $\begin{array}{l}\text { Must be available as either hardcover or paperback, must be registered on the amazon best sellers rank, } \\
\text { must be original work, only one book by author or author group }\end{array}$ \\
\hline
\end{tabular}

There was a language bias since only English books were selected. The Amazon.com sales rank was used as a popularity indicator and the forty most popular selected books were read. A data extraction form was filled out per book where main challenges targeted by the books and ideas about productivity were extracted. Table 5 shows an overview of the execution of the literature review of personal productivity self-help books.

Table 5. An overview of the literature review of personal productivity self-help books.

\begin{tabular}{|c|c|c|}
\hline Execution Step & Description & Results of the Execution \\
\hline Unrestricted book search & $\begin{array}{l}\text { Searched Amazon.com for each keyword } \\
\text { ordered by relevance }\end{array}$ & 41,097 book results \\
\hline \multirow[b]{2}{*}{ Restricted book search } & $\begin{array}{l}\text { 1. list of book categories manually reviewed } \\
\text { using an exclusion criteria checklist }\end{array}$ & 24 categories included \\
\hline & $\begin{array}{l}\text { 2. searched Amazon.com in included book } \\
\text { categories for each keyword ordered by } \\
\text { relevance }\end{array}$ & 1903 book results \\
\hline \multirow{2}{*}{ Book selection } & $\begin{array}{l}\text { 1. book results manually reviewed using a } \\
\text { selection criteria checklist }\end{array}$ & 272 books included \\
\hline & $\begin{array}{l}\text { 2. selected books ordered by ascending } \\
\text { Amazon sales rank }\end{array}$ & 40 most popular books read \\
\hline Data extraction & Data extraction forms filled out per book & 8 unique challenges identified \\
\hline
\end{tabular}

Table 6 shows the included book categories organized by their hierarchy. Each child category is subset of the parent. The books were extracted from the child book categories unless the parent category had fewer than a hundred books.

Table 6. Included book categories and their hierarchy.

\begin{tabular}{|c|c|c|}
\hline Included Parent & Included Children & Included Children ‘s Children \\
\hline \multirow[t]{2}{*}{ Business \& Investing } & Management \& Leadership & $\begin{array}{l}\text { Decision-Making \& Problem Solving, } \\
\text { Management, Management Science, Motivational }\end{array}$ \\
\hline & Skills & Time Management \\
\hline Professional \& Technical & Business Management & \\
\hline Health Fitness \& Dieting & Psychology \& Counseling & $\begin{array}{l}\text { Occupational \& Organizational, Personality, } \\
\text { Creativity \& Genius }\end{array}$ \\
\hline Self-Help & $\begin{array}{l}\text { Happiness, Motivational, Personal } \\
\text { Transformation, Self-Esteem, Stress Management, } \\
\text { Success, Creativity, Memory Improvement }\end{array}$ & \\
\hline
\end{tabular}


The information from both literature reviews was used in the next phase to express the problem situation.

\subsection{Problem Situation Expressed and Root Definitions Defined}

The first step was to identify the problem owners. A problem owner is someone who has a feeling of unease about a situation, senses inconsistencies in the system and feels that things could be better (Checkland 1993). The problem situation is viewed from the point of view of the problem owners. The problem owners were identified from common themes within the literature. To analyze the problem situation Checkland and Scholes (1999) recommend executing three analyses and drawing rich pictures of the problem situation. Table 7 gives an overview of these analyses.

Table 7. The three analyses.

\begin{tabular}{cll}
\hline & Analysis & \multicolumn{1}{c}{ Objective of Analysis (Checkland and Scholes 1999) } \\
\hline 1 & Intervention & $\begin{array}{l}\text { Identify the problem owners and how the system will be defined in terms of } \\
\text { their perceptions and knowledge }\end{array}$ \\
\hline 2 & Social system & $\begin{array}{l}\text { Identify roles (social positions recognized as significant by the problem } \\
\text { situation), norms (expected behaviors in roles) and values (how performance } \\
\text { will be judged) }\end{array}$ \\
\hline 3 & Political system & $\begin{array}{l}\text { The process by which differing interests reach accommodation. How is } \\
\text { power expressed? }\end{array}$ \\
\hline
\end{tabular}

This research was limited to the first analysis, of the intervention. The main objective of this research is to abstractify the problem situation and an analysis of the social system and political system goes into detail that would force a lower level of abstraction. The analysis of the intervention consisted of questions that the researchers answered using inferences made from the literature reviews. Appendix 2 in Checkland (1993) was used as a guideline when formulating the questions. Table 8 lists the questions.

Table 8. The questions of the analysis of intervention.

Questions
What is the problem owner's version of the nature of the problem?
What are the problem owner's reasons for regarding the problem as a problem?
What are the problem owner's expectations of a problem-solving system?

The next step was to draw rich pictures of the problem situation using the analysis of the intervention. Rich pictures are visual representations of the problem situation (Checkland 1993; Checkland and Scholes 1999). They are used to present the problem situation in a form that captures the different facets of a problem in a holistic way, helps identify themes in the system and create a mutual understanding of the problem (Checkland 1993; Checkland and Scholes 1999). Rich pictures do not have any formal modeling symbols since every problem situation is different. In this research to draw the pictures, verbs and nouns were extracted from the analysis of the intervention and the identified challenges from the literature reviews. The nouns became shapes and the verbs arrows that logically connected the shapes. Some of the concepts in the shapes had what were called needs, which were drawn as thought bubbles on the pictures. These needs were, for example, characteristics, actions or information that are not necessarily present, but could affect the problem situation. Speech bubbles were used to represent behavior of actors in the problem situation. Large arrows were used to highlight the verbs that have a direct effect on knowledge worker productivity. Solid green arrows have a positive effect but the striped red arrows a negative effect. Table 9 shows these different symbols: 
Table 9. The symbols used in the rich pictures.

Descriptions
and the challenges identified in the literature reviews.

From the interpretations of the rich pictures root definitions were defined for relevant systems. A root definition is a description of the system in the form of a transformation process in which some entity, input, is changed into a new form of the same entity, output (Checkland and Scholes 1999). To help define the system Checkland recommends using the acronym CATWOE. Table 10 shows what CATWOE stands for.

Table 10. CATWOE (Checkland and Scholes 1999).

\begin{tabular}{ccc}
\hline Letter & Stands for & Description \\
\hline $\mathrm{C}$ & Customers & The victims or beneficiaries of the transformation process (T). \\
$\mathrm{A}$ & Actors & Those who would do T. \\
$\mathrm{T}$ & Transformation process & The conversion of input-output. \\
$\mathrm{W}$ & Weltanschauung & The perspective which makes T meaningful in context. \\
$\mathrm{O}$ & Owner & Those who could stop T. \\
$\mathrm{E}$ & Environmental & Elements outside the system which it takes as given. \\
\hline
\end{tabular}

The next section presents the results from the two literature reviews. The papers and books were analyzed and similar ideas grouped together to give an overview of the main knowledge worker challenges being targeted.

\section{Knowledge Worker Productivity Challenges}

The literature review of academic papers was found to give insight into the problem from the perspective of organizations but the literature review of the industry proxy was designed to give insight into the problem from the perspective of individuals. The literature review of knowledge worker productivity challenges identified four main challenges targeted by the papers and eight main challenges targeted by industry. The next subsections go into these results in detail.

\subsection{Challenges Targeted by Current Research}

Thirty-nine papers were read with the intent of discovering what knowledge worker productivity challenges they were targeting. The main subjects of the papers were gathered and grouped by theme. Four main challenges were identified from the themes. The four main challenges are information needs and knowledge interdependence; motivation, work engagement and health; organizational structure and changes; and the nature of knowledge work. Most of the papers targeted the challenge 
of information needs and knowledge interdependence. The second most popular challenge was motivation, work engagement and health. Table 11 shows which papers targeted which challenge and an overview of the subjects of the papers.

Table 11. Subjects of challenges targeted by past research.

\begin{tabular}{|c|c|c|c|c|}
\hline Challenges & Subjects & Papers & $\begin{array}{l}\text { No. } \\
\text { Papers }\end{array}$ & $\begin{array}{c}\% \text { of } \\
\text { Read } \\
\text { Papers }\end{array}$ \\
\hline $\begin{array}{l}\text { Information needs } \\
\text { and knowledge } \\
\text { interdependence }\end{array}$ & $\begin{array}{l}\text { Information management of mobile } \\
\text { workers (Makinen 2012), managing email } \\
\text { (Kalman and Ravid 2015), ideal workforce } \\
\text { composites and distribution of } \\
\text { responsibility (Shao et al. 2014; } \\
\text { Delbridge et al. 2000), methods for } \\
\text { providing context-based information } \\
\text { (Lai 2015; Liu et al. 2012; Ke and Liu 2011; } \\
\text { Jung 2008; Liu and Ke 2007), knowledge } \\
\text { sharing (Hasan and Pfaff 2012; Ambos and } \\
\text { Schlegelmilch 2009; Li and Chang 2009; } \\
\text { Duguid 2006), knowledge management } \\
\text { (Seethamraju 2000; Barjis et al. 2011; } \\
\text { Chatti 2012; Ulbrich et al. 2014). }\end{array}$ & $\begin{array}{l}\text { (Seethamraju 2000; Makinen } \\
\text { 2012; Kalman and Ravid } \\
\text { 2015; Shao et al. 2014; } \\
\text { Delbridge et al. 2000; Lai } \\
\text { 2015; Liu et al. 2012; Ke and } \\
\text { Liu 2011; Jung 2008; Liu and } \\
\text { Ke 2007; Li and Chang 2009; } \\
\text { Ambos and Schlegelmilch } \\
\text { 2009; Duguid 2006; Barjis et } \\
\text { al. 2011; Chatti 2012; Ulbrich } \\
\text { et al. 2014) }\end{array}$ & 17 & $44 \%$ \\
\hline $\begin{array}{l}\text { Motivation, work } \\
\text { engagement and } \\
\text { health }\end{array}$ & $\begin{array}{l}\text { Motivation and autonomy (Gambardella et } \\
\text { al. 2015; Gleadle et al. 2012), motivating } \\
\text { dispersed workers (Keneley 2008; } \\
\text { Mudambi et al. 2007), organizational } \\
\text { commitment (Hwang and Yoo 2012; } \\
\text { Manville and Obe 2003; Stanton 1972), } \\
\text { workplace boredom (Van der Heijden et al. } \\
\text { 2012), value congruence and work } \\
\text { engagement (Dylag et al. 2013), social } \\
\text { relationships in the workplace (Agumba } \\
\text { and Fester 2010; Ditton 2009), work hours } \\
\text { and health (Kwon et al. 2014), health } \\
\text { problems in knowledge work (Richardson } \\
\text { and Larsen 1997). }\end{array}$ & $\begin{array}{l}\text { (Gambardella et al. 2015; } \\
\text { Gleadle et al. 2012; Keneley } \\
\text { 2008; Mudambi et al. 2007; } \\
\text { Hwang and Yoo 2012; } \\
\text { Manville and Obe 2003; } \\
\text { Stanton 1972; Van der } \\
\text { Heijden et al. 2012; Dylag et } \\
\text { al. 2013; Agumba and Fester } \\
\text { 2010; Ditton 2009; Kwon et } \\
\text { al. 2014; Richardson and } \\
\text { Larsen 1997) }\end{array}$ & 13 & $33 \%$ \\
\hline $\begin{array}{l}\text { Organizational } \\
\text { structure and } \\
\text { changes }\end{array}$ & $\begin{array}{l}\text { Identities within ever-changing workplaces } \\
\text { (Amidon and Blythe 2008), problems with } \\
\text { complex structures and processes (Vaughan } \\
\text { 1999), refocus priorities within fast } \\
\text { changing organizations using critical } \\
\text { success factors (Bullen 1995), shift focus } \\
\text { from production to knowledge work (Hori } \\
\text { 1993), need for capital investment for the } \\
\text { office worker (Devilliers 1980). }\end{array}$ & $\begin{array}{l}\text { (Amidon and Blythe 2008; } \\
\text { Vaughan 1999; Bullen 1995; } \\
\text { Hori 1993; Devilliers 1980) }\end{array}$ & 5 & $13 \%$ \\
\hline $\begin{array}{l}\text { Nature of } \\
\text { knowledge work }\end{array}$ & $\begin{array}{l}\text { Differences between manual work and } \\
\text { knowledge work (Drucker 1999; Martin } \\
\text { 2013), an empirically informed analysis of } \\
\text { knowledge work is needed (Darr and } \\
\text { Warhurst 2008), a need to change how we } \\
\text { learn (Garrick and Clegg 2001). }\end{array}$ & $\begin{array}{l}\text { (Drucker 1999; Martin 2013; } \\
\text { Darr and Warhurst 2008; } \\
\text { Garrick and Clegg 2001) }\end{array}$ & 4 & $10 \%$ \\
\hline
\end{tabular}

After analyzing the main challenges of the thirty-nine papers in the literature review of knowledge worker challenges the following inferences were drawn about the four main challenges identified. The challenge of information needs and knowledge interdependence emphasizes the fact that knowledge workers need to work together to achieve organizational goals. They need to obtain the information that they need to solve problems and manage it (Lai 2015; Ke and Liu 2011; Jung 2008; Liu and Ke 2007; Hasan and Pfaff 2012; Li and Chang 2009). They need to transfer their own knowledge to others to contribute to the organization (Hasan and Pfaff 2012; Ambos and Schlegelmilch 2009; Li and Chang 2009; Duguid 2006). Knowledge workers are sometimes hesitant to share their knowledge since they recognize the power it gives them and do not want to become redundant. Organizations often divide 
workers into segments around divisions of knowledge (Duguid 2006). This can make knowledge sharing even more problematic and create tensions because of misunderstanding between the groups (Duguid 2006). Organizations become composites of many communities of practice whose differences create internal divisions instead of being an aggregate of individuals united in an organizational culture (Duguid 2006). Organizations must therefore develop a knowledge-sharing environment with appropriate systems and policies for knowledge management to support knowledge workers (Seethamraju 2000). The challenge from the perspective of organizations is creating a knowledge sharing environment and promoting collaboration while preserving opportunities for the individual to see impact of his own personal contribution.

That is where the challenge of motivation, work engagement and health comes in. Knowledge workers want the freedom to use their capabilities and feel competent (Muller-Smith 1997). Autonomy has been recognized as an important factor in motivating knowledge workers and increasing their commitment to the organization (Gambardella et al. 2015; Gleadle et al. 2012; Hwang and Yoo 2012). The worker's level of engagement has an effect on his performance. Van der Heijden et al. (2012) found that workers with high time management skills were less likely to be distracted as a result of workplace boredom. Dylag et al. (2013) found that if there was a conflict between a worker's personal values and the organizations there was a higher risk of professional exhaustion and decrease in work engagement. The work environment affects the mental and physical health of the knowledge worker (Ditton 2009; Kwon et al. 2014; Richardson and Larsen 1997). The challenge for the organization is creating a work environment, which promotes health, motivates and engages their workers, to get optimum performance from them and make them want to work for the organization.

Organizational structure and changes focuses on the external system that is influencing organizations as well as knowledge workers and its increasing complexity. The organization needs to figure out what structure will not hinder the performance of their knowledge workers and fulfill the requirements of their customers, industry standards, cultures and other stakeholders (Amidon and Blythe 2008; Vaughan 1999; Bullen 1995; Hori 1993). The complexity of organizational structures is increasing with globalization, outsourcing, mobile workers and need for cross-functional teams (Amidon and Blythe 2008). There is a need to understand the nature of knowledge work and the knowledge worker to fully grasp the challenge of knowledge worker productivity. Darr and Warhurst (2008) state that an empirically informed analysis of the knowledge worker's work is required to fully understand the productivity challenge. It is not enough to analyze the inputs or outputs of knowledge work, it is equally important to analyze the work practices themselves and the transformation (Darr and Warhurst 2008). Table 12 shows an overview of the discussed conclusions.

Table 12. Summary of inferences drawn about the challenges targeted by past research.

\begin{tabular}{ll}
\hline \multicolumn{1}{c}{ Challenges } & \multicolumn{1}{c}{ Inferences Drawn about the Challenge } \\
\hline $\begin{array}{l}\text { Information needs and } \\
\text { knowledge } \\
\text { interdependence }\end{array}$ & $\begin{array}{l}\text { The organization needs to create a knowledge sharing environment and promoting } \\
\text { collaboration while preserving opportunities for the individual to see impact of his } \\
\text { own personal contribution. }\end{array}$ \\
\hline $\begin{array}{l}\text { Motivation, work } \\
\text { engagement and health }\end{array}$ & $\begin{array}{l}\text { The organization needs to create a work environment, which promotes health, } \\
\text { motivates and engages their workers, to get optimum performance from them and } \\
\text { make them want to work for the organization. }\end{array}$ \\
\hline $\begin{array}{l}\text { Organizational structure } \\
\text { and changes }\end{array}$ & $\begin{array}{l}\text { The organization needs to figure out what structure will not hinder the } \\
\text { performance of their knowledge workers yet fulfill the requirements of their } \\
\text { customers, industry standards, cultures and other stakeholders. }\end{array}$ \\
\hline Nature of knowledge work & $\begin{array}{l}\text { There is a need to understand the nature of knowledge work and the knowledge } \\
\text { worker to fully grasp the challenge of knowledge worker productivity. }\end{array}$ \\
\hline
\end{tabular}

The next section presents the results from the literature review of a proxy for industry, which give an insight into the challenges of the individual knowledge worker. 


\subsection{Challenges Targeted by Industry}

Forty popular personal productivity self-help books were analyzed, as a proxy for industry. The assumption was that they would give insight into the challenges experienced by the individual knowledge worker within organizations from the perspective of consultants and the knowledge worker himself. The primary and secondary subjects of the books were gathered and grouped by theme. The primary subjects reflect the main themes of the books and the secondary subjects, other themes that the books also emphasized. Table 13 shows which books target which primary challenges.

Table 13. Primary challenges targeted by the books.

\begin{tabular}{|c|c|c|c|}
\hline Primary Challenges & Books & $\begin{array}{l}\text { No. } \\
\text { Books }\end{array}$ & $\begin{array}{l}\% \text { of } \\
\text { Read } \\
\text { Books }\end{array}$ \\
\hline $\begin{array}{l}\text { Too much demand and } \\
\text { insufficient resources }\end{array}$ & $\begin{array}{c}\text { (Allen 2001; Tracy 2013; Leland and Bailey 2008; Perry } \\
\text { 2012; Song et al. 2007; Pash and Trapani 2011; Chandler } \\
\text { 2011; Vanderkam 2010; Stack 2004; Henry 2011; Harvard } \\
\text { Business Essentials 2005) }\end{array}$ & 11 & $28 \%$ \\
\hline $\begin{array}{l}\text { Self-development and } \\
\text { self-awareness }\end{array}$ & $\begin{array}{c}\text { (Covey 2004; Hubbard 2011; Duhigg 2012; Tan 2012; } \\
\text { Blanchard et al. 2005; Goleman 1999; Baumeister and } \\
\text { Tierney 2011; Deci 1995) }\end{array}$ & 8 & $20 \%$ \\
\hline Effectiveness & $\begin{array}{l}\text { (Drucker 1966; Covey et al. 1994; Koch 2008; Meier 2010; } \\
\text { Stanier 2010; Bennington and Lineberg 2010) }\end{array}$ & 6 & $15 \%$ \\
\hline $\begin{array}{l}\text { Achieving and/or } \\
\text { setting goals }\end{array}$ & $\begin{array}{l}\text { (Selk 2009; Moran and Lennington 2013; Holden 2012; } \\
\text { Scott 2004; Lewis 2012; Babauta 2008) }\end{array}$ & 6 & $15 \%$ \\
\hline $\begin{array}{l}\text { Performing to full } \\
\text { potential }\end{array}$ & $\begin{array}{l}\text { (Loehr and Schwartz 2003; Greenblatt 2009; Schwartz et al. } \\
\text { 2010; Kelley 1998a, 1998b; Gleeson 2009) }\end{array}$ & 5 & $13 \%$ \\
\hline $\begin{array}{l}\text { Making thinking more } \\
\text { productive }\end{array}$ & $\begin{array}{c}\text { (Checkland 1993; De Bono 2000; Paul and Elder 2013; } \\
\text { Maxwell 2009) }\end{array}$ & 4 & $10 \%$ \\
\hline
\end{tabular}

The primary challenges identified were: too much demand and insufficient resources; self-development and self-awareness; effectiveness; achieving and/or setting goals; performing to full potential and making thinking more productive. The following inferences were drawn about these six primary challenges. Too much demand and insufficient resources was the most common challenge within the books. The individual knowledge worker needs to deal with demands from himself, the organization and each role in his social system using his personal resources, knowledge, available information and available time. When the worker binds emotionally or intellectually to a demand it becomes a commitment (Moran and Lennington 2013). Having too many commitments can quickly overwhelm the worker, making it harder to keep them (Allen 2001; Leland and Bailey 2008; Meier 2010). A lot of the stress workers experience comes from badly managed commitments, which pull at the worker's attention (Allen 2001). The most popular solution to this challenge was time management, which focuses on minimizing time-wasters, being aware of time in relationship to the tasks and improving time-task effectiveness (Drucker 1966; Allen 2001; Leland and Bailey 2008; Covey 2004).

The challenge of self-development and self-awareness touches on the fact that the knowledge worker needs to know what his personal resources are to utilize them to improve his personal productivity, motivate himself to get things done and handle the pressures of the demands made on him. Personal resources can be grouped into physical, emotional, social and cognitive resources. Physical resources are the individual's strength, endurance and restfulness, which stems from sleep, nutrition, exercise and breathing (Loehr and Schwartz 2003; Greenblatt 2009; Schwartz et al. 2010). Emotional resources are the individuals' emotional capacities and perceived experiences, which include self-control, self-esteem and empathy (Loehr and Schwartz 2003; Greenblatt 2009; Schwartz et al. 2010). 
Social resources include social skills, communication, sense of connectedness to others and spiritualism, which comes from the individual's connection to deeply held values, purposes and vision (Loehr and Schwartz 2003; Greenblatt 2009; Schwartz et al. 2010). Cognitive resources are the worker's natural and learned intellectual capacities and his ability to access them (Loehr and Schwartz 2003; Greenblatt 2009; Schwartz et al. 2010). Self-development is the process of developing competences, acquiring new skills and learning (Tracy 2013; Goleman 1999; Covey et al. 1994) while self-awareness is the workers knowledge of his own internal states, preferences, resources and intuitions (Goleman 1999). To improve self-awareness and increase self-development the books suggest tools such as mindfulness; identifying strengths, weaknesses, personal values, principles and a personal vision; changing perspectives and attitudes; continuous learning and focusing on continuous improvement.

Effectiveness is doing the right thing or getting the right results, which is third most common challenge (Tangen 2005). The challenge is knowing which tasks to focus on to create value for the organization, the individual knowledge worker or others. The books agree that the knowledge worker needs to identify his key result areas. Key result areas of the knowledge worker's job are where he can utilize his strengths, knowledge and competence to contribute the most to the performance and results of the organization (Drucker 1966; Tracy 2013; Covey et al. 1994; Koch 2008; Moran and Lennington 2013). Key result areas are where talent, passion and value meet (Meier 2010). The rest of the challenges identified are related to the first three. The challenge of achieving and/or setting goals stems from the popularity of goals as tools to help the knowledge worker get the right things done and get the right results, in other words be effective. Goals are statements of what the worker wants to achieve or how he will achieve it (Selk 2009).

Performing to full potential is the challenge of managing the personal resources the knowledge worker has identified with self-awareness and nurtured with self-development. Every thought, feeling and action has an effect on the worker's personal resources; some of them deplete resources while others restore resources (Loehr and Schwartz 2003; Greenblatt 2009; Schwartz et al. 2010). Most activities can both restore and deplete different resources and their effects change throughout life (Greenblatt 2009). A worker can use self-awareness to identify what effect activities have on their personal resources and invest time in balancing restoration and depletion to minimize the risk of burnout (Meier 2010; Loehr and Schwartz 2003; Schwartz et al. 2010). The most common restorers are sleep, working within your strengths, sunlight and exercise (Greenblatt 2009). The most common depleters are emotional labor, interruptions and cultures of relentless enthusiasm (Greenblatt 2009). Making thinking more productive is a specific challenge that arises because of nature of knowledge work. Thinking is using data, facts and experiences to make inferences and judgments to create meaning, answer questions or solve problems (Paul and Elder 2013). Thinking is a skill the knowledge worker needs to use in everything he does. Making thinking more productive can increase knowledge creation, decrease mistakes of judgment, increase creativity and allow the worker to better assess risk (Loehr and Schwartz 2003).

Most of the secondary challenges, that the books target, are the same as the primary challenges in other books. New challenges identified as secondary are successful relationships and collaborations and motivation. Table 14 shows which books target which secondary challenge.

Twelve books targeted the secondary challenge of successful relationships and collaborations. The knowledge worker only has part of the knowledge needed to get his job done, so collaborating is vital (Goleman 1999). He is only effective if and when other people make use of what he contributes (Drucker 1966). Relationships are connections between people comprising of mutual enjoyment, respect, shared experiences, reciprocity and trust (Koch 2008). Healthy relationships can be a powerful source of both positive energy and of renewal (Lewis 2012; Schwartz et al. 2010). Creating relationships to proactively develop dependable pathways to experts that can help the worker complete tasks is called networking (Kelley 1998a, 1998b). The books that targeted this challenge focused on knowledge sharing, understanding the perspective of others, having compassion, communication, leadership, followership and getting the support that the knowledge worker needs to get his job done. The 
challenge of successful relationships and collaborations stems from the interdependence between knowledge workers and the human need to feel connected with others.

Table 14. Secondary challenges targeted by the books.

\begin{tabular}{|c|c|c|c|}
\hline Secondary challenges & Books & $\begin{array}{l}\text { No. } \\
\text { Books }\end{array}$ & $\begin{array}{l}\% \text { of } \\
\text { Read } \\
\text { Books }\end{array}$ \\
\hline $\begin{array}{l}\text { Successful relationships } \\
\text { and collaborations }\end{array}$ & $\begin{array}{l}\text { (Drucker 1966; Song et al. 2007; Covey 2004; Tan 2012; } \\
\text { Blanchard et al. 2005; Goleman 1999; Covey et al. 1994; } \\
\text { Koch 2008; Scott 2004; De Bono 2000; Maxwell 2009; Kelley } \\
\text { 1998a, 1998b) }\end{array}$ & 12 & $28 \%$ \\
\hline Effectiveness & $\begin{array}{l}\text { (Allen 2001; Tracy 2013; Perry 2012; Vanderkam 2010; } \\
\text { Harvard Business Essentials 2005; Moran and Lennington } \\
\text { 2013; Lewis 2012; Babauta 2008; Meadows 2008) }\end{array}$ & 9 & $23 \%$ \\
\hline $\begin{array}{l}\text { Achieving and/or } \\
\text { setting goals }\end{array}$ & $\begin{array}{l}\text { (Leland and Bailey 2008; Pash and Trapani 2011; Stack } \\
\text { 2004; Duhigg 2012; Baumeister and Tierney 2011; Stanier } \\
\text { 2010; Gleeson 2009) }\end{array}$ & 7 & $13 \%$ \\
\hline $\begin{array}{l}\text { Self-development and } \\
\text { self-awareness }\end{array}$ & $\begin{array}{l}\text { (Henry 2011; Bennington and Lineberg 2010; Selk 2009; } \\
\text { Loehr and Schwartz 2003; Greenblatt 2009; Schwartz et al. } \\
\text { 2010; Paul and Elder 2013) }\end{array}$ & 7 & $13 \%$ \\
\hline Motivation & (Chandler 2011; Hubbard 2011; Deci 1995; Meier 2010) & 5 & $10 \%$ \\
\hline
\end{tabular}

Motivation is defined as an affective state that arouses a worker to action, directs, persists and engages him in certain activities (Cheng and Yeh 2009). Motivation can be intrinsic or extrinsic (Drucker 1966; Deci 1995; Meier 2010; Stanier 2010; Lewis 2012; Loehr and Schwartz 2003). Intrinsic motivation comes from the worker's thoughts, feelings or body (Meier 2010; Loehr and Schwartz 2003) while extrinsic motivation is when the worker is motivated by rewards, punishment or other external motivators (Meier 2010; Loehr and Schwartz 2003). Intrinsic motivation is at the heart of creativity, accountability, healthy behavior and lasing change (Deci 1995). The books that targeted this challenge focused on intrinsic motivators such as autonomy, competence, purpose, vision, a compelling why, compelling outcomes and sense of accomplishment through small wins. The challenge of motivation for the individual knowledge worker is finding and nurturing intrinsic motivation to arouse himself to action and get things done. Table 15 shows an overview of the inferences made about each of the eight challenges identified in the personal productivity self-help books.

Table 15. Summary of inferences drawn about the challenges targeted by the books.

\begin{tabular}{ll}
\hline \multicolumn{1}{c}{ Challenges } & \multicolumn{1}{c}{ Inferences Drawn about the Challenge } \\
\hline $\begin{array}{l}\text { Too much demand } \\
\text { and insufficient } \\
\text { resources }\end{array}$ & $\begin{array}{l}\text { The individual knowledge worker needs to deal with demands from himself, the } \\
\text { organization and each role in his social system using his personal resources, } \\
\text { knowledge, available information and available time. }\end{array}$ \\
\hline Effectiveness & $\begin{array}{l}\text { The individual knowledge worker cannot fulfill every demand on him, he needs to } \\
\text { choose what to do, how to do it and when to do it. The challenge is knowing which } \\
\text { tasks to focus on to create value for the organization, the individual knowledge worker } \\
\text { or others in his social system. }\end{array}$ \\
\hline $\begin{array}{l}\text { Self-development } \\
\text { and self-awareness }\end{array}$ & $\begin{array}{l}\text { The knowledge worker needs to know what his personal resources are to utilize them } \\
\text { to improve his effectiveness, efficiency, motivate himself to get things done and handle } \\
\text { the pressures of the demands made on him as well as know which competences and } \\
\text { skills he needs to develop. }\end{array}$ \\
\hline $\begin{array}{l}\text { Achieving and/or } \\
\text { setting goals }\end{array}$ & $\begin{array}{l}\text { The challenge of achieving and/or setting goals stems from the popularity of goals as } \\
\text { tools to help the knowledge worker get the right things done and get the right results, } \\
\text { in other words be effective. The challenge is successfully using this tool. }\end{array}$ \\
\hline
\end{tabular}


Table 15. Cont.

\begin{tabular}{ll}
\hline \multicolumn{1}{c}{ Challenges } & \multicolumn{1}{c}{ Inferences Drawn about the Challenge } \\
\hline $\begin{array}{l}\text { Performing to full } \\
\text { potential }\end{array}$ & $\begin{array}{l}\text { Performing to full potential is the challenge of managing the personal resources the } \\
\text { worker has identified with self-awareness and nurtured with self-development } \\
\text { (includes issues such as health, stress, exhaustion and psychological distress). }\end{array}$ \\
\hline $\begin{array}{l}\text { Making thinking } \\
\text { more productive }\end{array}$ & $\begin{array}{l}\text { Thinking is a skill the knowledge worker needs to use in everything he does. Making } \\
\text { thinking more productive can increase knowledge creation, decrease mistakes of } \\
\text { judgment, increase creativity and allow the worker to better assess risk } \\
\text { (Loehr and Schwartz 2003). }\end{array}$ \\
\hline $\begin{array}{l}\text { Successful } \\
\text { relationships and } \\
\text { collaborations }\end{array}$ & $\begin{array}{l}\text { The challenge of successful relationships and collaborations stems from knowledge } \\
\text { worker interdependence and the human need to feel connected with others. }\end{array}$ \\
\hline Motivation & $\begin{array}{l}\text { The challenge of motivation for the individual knowledge worker is finding and } \\
\text { nurturing intrinsic motivation to arouse himself to action and get things done. }\end{array}$ \\
\hline
\end{tabular}

The next sections describe the results of the problem situation analysis, rich pictures and root definitions.

\section{Problem Situation—Rich Pictures and Root Definitions}

The organization and the individual knowledge worker were identified as the problem owners of the system based on the results of the literature reviews. An analysis of the intervention was performed for both problem owners by drawing conclusions from literature to answer the questions posed in section 2.3. Table 16 shows the results of this analysis.

Table 16. Analyses of the intervention, leading questions and answers (Checkland 1993).

\begin{tabular}{|c|c|c|}
\hline \multirow{2}{*}{ Question } & \multicolumn{2}{|c|}{ Answer for Each Problem Owner: } \\
\hline & Individual & Organization \\
\hline $\begin{array}{l}\text { The problem owner's } \\
\text { version of the nature } \\
\text { of the problem is: }\end{array}$ & $\begin{array}{l}\text { Low knowledge worker productivity is a } \\
\text { problem for the individual knowledge worker } \\
\text { because of the shift of responsibility of } \\
\text { productivity from the organization to the } \\
\text { individual. The individual knowledge worker is } \\
\text { expected to manage and be accountable for his } \\
\text { own career advancement, professional } \\
\text { development and contribution to the } \\
\text { organization (Drucker 1999; Letiche and van } \\
\text { Hattem 2000). }\end{array}$ & $\begin{array}{l}\text { Low knowledge worker productivity is a } \\
\text { problem because the organization is } \\
\text { dependent on knowledge workers to } \\
\text { create value and contribute to the } \\
\text { organizational knowledge base that is the } \\
\text { organization's competitive advantage } \\
\text { (Jayasingam and Yong 2013; } \\
\text { Jayasingam et al. 2016). }\end{array}$ \\
\hline $\begin{array}{l}\text { The problem owner's } \\
\text { reasons for regarding } \\
\text { the problem as a } \\
\text { problem are: }\end{array}$ & $\begin{array}{l}\text { Those who cannot keep up with the demands of } \\
\text { the autonomy and accountability resulting from } \\
\text { this shift experience stress and exhaustion } \\
\text { (Letiche and van Hattem 2000). }\end{array}$ & $\begin{array}{l}\text { Being dependent on knowledge workers } \\
\text { is a problem because they are human } \\
\text { beings who have different needs that } \\
\text { need to be fulfilled to get the optimum } \\
\text { performance from them. }\end{array}$ \\
\hline $\begin{array}{l}\text { The problem owner's } \\
\text { expectations of a } \\
\text { problem-solving } \\
\text { system are: }\end{array}$ & $\begin{array}{l}\text { A system that supports the individual knowledge } \\
\text { worker in managing his own career advancement, } \\
\text { professional development and contribution to the } \\
\text { organization. }\end{array}$ & $\begin{array}{l}\text { A system that allows the organization to } \\
\text { increase the value contribution of their } \\
\text { knowledge workers and retain workers. }\end{array}$ \\
\hline $\begin{array}{l}\text { The assumed value of } \\
\text { a problem-solving } \\
\text { system is: }\end{array}$ & $\begin{array}{l}\text { Supporting the individual knowledge worker in } \\
\text { managing his own career advancement, } \\
\text { professional development and contribution to the } \\
\text { organization would allow them to deal with the } \\
\text { increased demands and not experience stress and } \\
\text { exhaustion increasing their overall personal } \\
\text { productivity and satisfaction in life. }\end{array}$ & $\begin{array}{l}\text { Increasing the value contribution of their } \\
\text { knowledge workers and retaining them } \\
\text { would allow the organization to gain } \\
\text { competitive advantage and decrease } \\
\text { overhead due to less turnover and better } \\
\text { use of resources. }\end{array}$ \\
\hline
\end{tabular}


The analysis above and the identified challenges were used to create rich pictures of the problem situation and define root definitions. The rich pictures give a simplified visual description of the problem situation from the perspective of the two problem owners, individual and organization. The root definitions describe the system in the form of a transformation process. The next sections present these rich pictures and root definitions for each of the problem owners.

\subsection{Organization as Problem Owner}

Figure 1 shows a rich picture of the problem situation from the perspective of the organization. The organization has some organizational objectives and needs which are influenced by external factors such as customers, industry standards and business environment. The organization must communicate what is value to them through their organizational objectives and needs. The solid green arrow shows that knowledge worker productivity increases if knowledge workers fulfill demands that create value. The striped red arrow from the knowledge workers shape shows that overall knowledge worker productivity decreases if the workers fulfill demands that are time-wasters. Demands that do not contribute to organizational objectives and needs are usually a waste of time.

The organization creates a work environment that fulfills the needs of some knowledge workers, but might not fulfill the need of others. The work environment consists of tangible and intangible things such as the organizational structure, work design, technology, incentives and culture. According to the results of the literature review of academic papers the work environment needs to promote health, collaboration and knowledge sharing as well as engage and motivate knowledge workers to improve their performance. If a work environment does not fulfill the needs of knowledge workers they will underperform, which will have a negative effect on overall knowledge worker productivity. If their needs are unmet for long it is likely that they will quit, increasing turnover. A high turnover rate means a lot of knowledge is lost from the organizational knowledge base. The organizational knowledge base gives the organization competitive advantage.

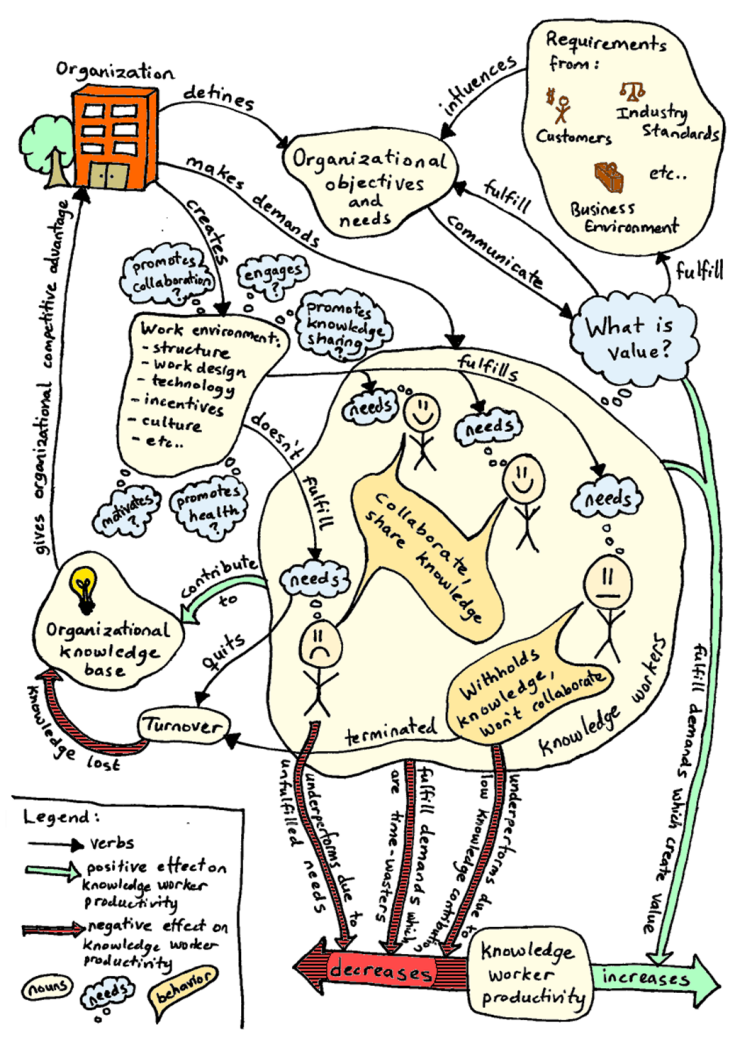

Figure 1. Rich picture of the problem situation with the organization as the problem owner. 
Knowledge workers within an organization are usually interdependent. They rarely have all the knowledge or skills needed to achieve organizational objectives. By sharing knowledge and collaborating, knowledge workers strengthen the organizational knowledge base and less knowledge is lost due to turnover. Therefore, knowledge workers that refuse to collaborate and withhold knowledge underperform due to restricted access to resources, such as knowledge or skills their co-workers possess, and they contribute less to the organizational knowledge base. If these workers continue to underperform they might get dismissed leading to higher turnover and knowledge loss. From the rich picture three main conclusions can be made about the problem situation of low knowledge worker productivity from the perspective of the organization. Table 17 shows these conclusions.

Table 17. Main conclusions from the rich picture with the organization as the problem owner.

\begin{tabular}{l}
\hline Main Conclusions \\
The organization must communicate organizational objectives and needs so knowledge workers can fulfill \\
demands that create value and not waste time on the wrong things. \\
\hline The work environment needs to promote collaboration and knowledge sharing to facilitate knowledge worker \\
contribution to the organizational knowledge base, which gives the organization competitive advantage. Also, \\
knowledge workers who withhold knowledge and won't collaborate underperform due to restricted access to \\
resources. \\
The work environment needs to fulfill the needs of the knowledge workers to get optimum performance from \\
them. A knowledge worker whose needs are unfulfilled will underperform.
\end{tabular}

From the conclusions above the organization has control over the work environment. According to these results, the organization should be able to improve knowledge worker productivity by creating a work environment that supports the needs of the knowledge workers and influences them to achieve organizational objectives. The root definition was defined from the conclusions of the rich pictures and a CATWOE analysis (Table 18).

Table 18. CATWOE for a system owned by the organization.

\begin{tabular}{|c|c|c|}
\hline Letter & Stands for & System Owned by the Organization \\
\hline $\mathrm{C}$ & Customers & Organization \\
\hline A & Actors & Knowledge Worker \\
\hline $\mathrm{T}$ & Transformation process & $\begin{array}{l}\text { Perceived effort of knowledge workers transformed into } \\
\text { perceived value by the organization }\end{array}$ \\
\hline W & Weltanschauung (Perspective) & $\begin{array}{l}\text { Knowledge worker productivity can be improved by supporting } \\
\text { the needs of the knowledge workers and influencing them to } \\
\text { achieve organizational objectives }\end{array}$ \\
\hline $\mathrm{O}$ & Owner & Organization \\
\hline E & Environmental constraints & Business environment, industry standards, culture, etc. \\
\hline
\end{tabular}

The CATWOE analysis showed that the organization benefits of a transformation, executed by the knowledge worker, of perceived effort of the individual knowledge worker into perceived value by the organization. The perspective (weltanschauung) is that knowledge worker productivity can be improved by supporting the needs of the knowledge workers and influencing them to achieve organizational objectives. The root definition is stated in Table 19. 
Table 19. Root definition of a system owned by the organization.

\begin{tabular}{l}
\hline Root definition-Organization \\
A system, owned by the organization, which transforms perceived effort of knowledge workers into perceived \\
value by the organization by creating a work environment, which supports the needs of the workers and \\
influences them to increase their value contribution to the organization.
\end{tabular}

The next section presents a rich picture of the problem situation from the perspective of the individual knowledge worker and defines a root definition of a system owned by him.

\subsection{Individual Knowledge Worker as Problem Owner}

The problem situation from the perspective of the individual knowledge worker stems from the shift of responsibility of productivity from the organization to the individual. Figure 2 shows a rich picture of the problem situation from the perspective of the individual knowledge worker. The knowledge worker has personal resources and competences. His competences consist of, for example, his knowledge, skills, perspective and networks. The knowledge worker uses his competences in everything he does. Self-awareness allows the worker to identify his competences, so that the worker can utilize his strengths and compensate for his weaknesses. It can also be used to identify opportunities for self-development and create intrinsic motivation. Motivation is necessary to arouse the worker to action, direct, persist and engage him in certain activities (Cheng and Yeh 2009). Intrinsic motivation comes from the worker's thoughts, feelings or body (Meier 2010; Loehr and Schwartz 2003) while extrinsic motivation comes from external rewards or punishment such as pay, incentives and reprimands. Organizations can use motivators to try to motivate workers to want to work and create value for them.

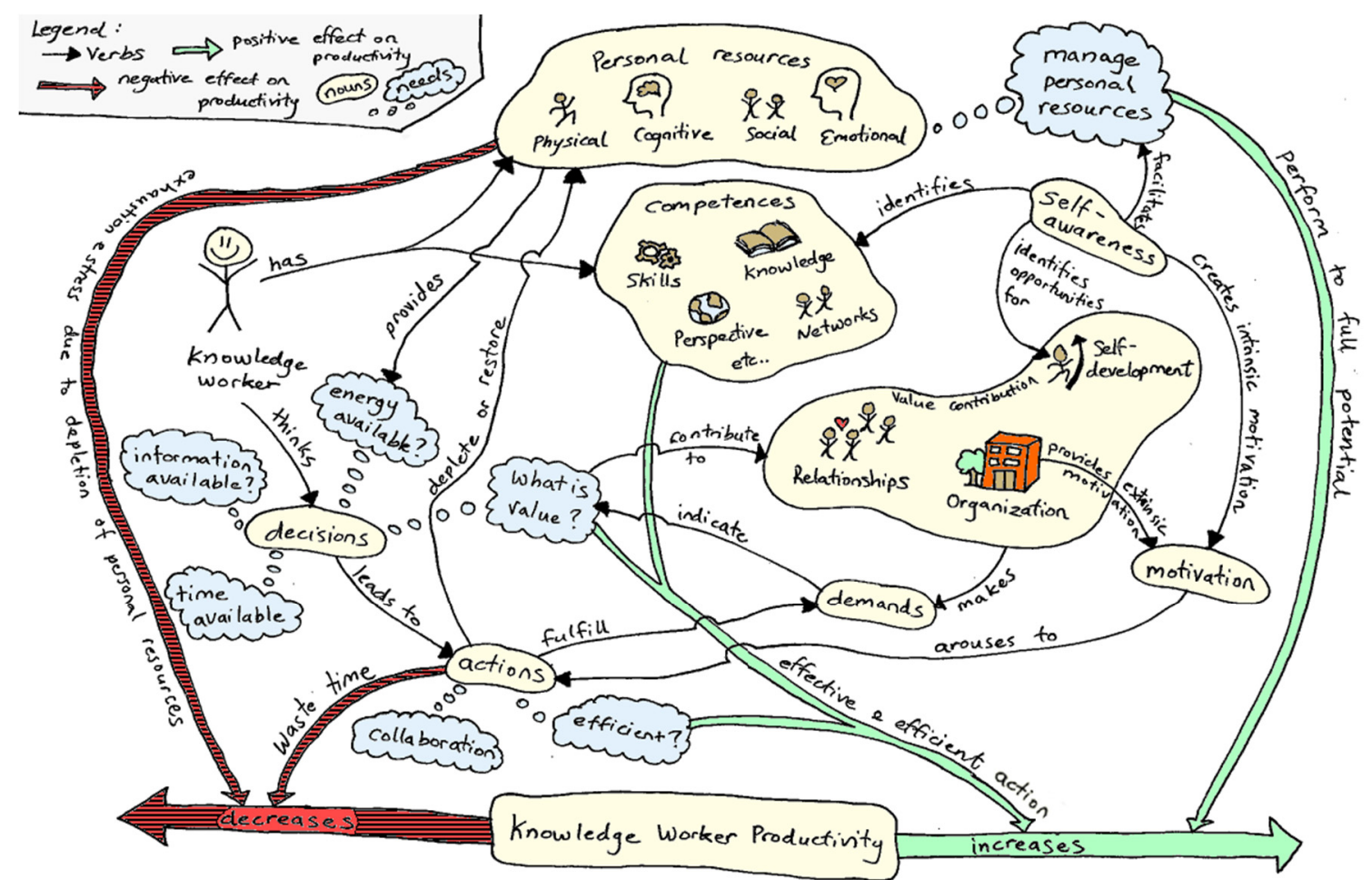

Figure 2. Rich picture of the problem situation with the individual as the problem owner.

Self-awareness facilitates personal resource management because the knowledge worker becomes more in tune with his state and needs. Personal resources can be grouped into physical, cognitive, 
social and emotional resources as discussed in Section 3.2. If the knowledge worker manages his personal resources, he can perform to his full potential improving his productivity. If the knowledge worker depletes his personal resources, he may suffer from exhaustion and stress. Exhaustion and stress lowers his ability to perform and therefore his productivity.

The knowledge worker thinks and makes decisions that lead to actions. When making decisions the worker needs to take in account time available, information available, energy available and what would create value. The state of his personal resources provides the knowledge worker with a sense his available energy. Every action he takes either depletes personal resources or restores them. Actions may require collaboration and can usually be done in more than one way. The knowledge worker should strive to do things efficiently. The knowledge worker needs to know what actions create value to be effective. The knowledge worker can usually create value by contributing to relationships, the organization or self-development. Relationships fulfill the human need to feel connected with others, facilitate collaboration and are the foundation of networks, which give the worker access to resources. The knowledge worker creates value for the organization by contributing to its organizational objectives and needs. Self-development allows the knowledge worker to acquire new competences and increase his personal resources, improving his performance. These three groups all make demands on the knowledge worker, which he fulfills with his actions. The demands from these groups also give the worker an indication of what is value. The knowledge worker increases his productivity by being effective and efficient. He is effective if he utilizes his competences and strives to create value. Actions taken which do not create value are a waste of time.

From the rich picture, two main conclusions can be made about the problem situation of low knowledge worker productivity from the perspective of the individual knowledge worker. Table 20 shows these conclusions.

Table 20. Main conclusions from the rich picture with the individual knowledge worker as the problem owner.

\section{Main Conclusions}

The individual knowledge worker must manage his personal resources to perform to his full potential. If he depletes his personal resources he experiences exhaustion and stress which lower his performance.

The individual knowledge worker must be effective and efficient and not waste energy and time on actions that do not create value.

A CATWOE analysis was executed to explore a relevant system owned by the individual. The transformation is the same regardless of problem owner only the perspective (weltanschauung) has changed. The perspective is that the knowledge worker can improve his productivity by managing his personal resources, being effective and efficient. Table 21 shows the CATWOE analysis for a system owned by the individual.

Table 21. CATWOE for a system owned by the individual.

\begin{tabular}{ccl}
\hline Letter & Stands for & \multicolumn{1}{c}{ System Owned by the Individual } \\
\hline $\mathrm{C}$ & Customers & Organization \\
\hline $\mathrm{A}$ & Actors & Knowledge worker \\
\hline $\mathrm{T}$ & Transformation process & $\begin{array}{l}\text { Perceived effort of the individual knowledge worker } \\
\text { transformed into perceived value by the organization }\end{array}$ \\
\hline $\mathrm{W}$ & Weltanschauung (perspective) & $\begin{array}{l}\text { The knowledge worker can improve his productivity by } \\
\text { managing his personal resources, being effective and efficient }\end{array}$ \\
\hline $\mathrm{O}$ & Owner & Individual \\
\hline $\mathrm{E}$ & Environmental constraints & Laws, culture etc. \\
\hline
\end{tabular}


Table 22 states the root definition of a system owned by the individual defined from the rich picture and the CATWOE analysis. The root definition focuses on the productivity of the individual knowledge worker.

Table 22. Root definition of a system owned by the individual.

\section{Root definition-Individual}

A system, owned by the individual, which transforms perceived effort of the individual knowledge worker into perceived value by the organization by managing personal resources, being effective and efficient.

The next section discusses the results of this paper and contemplates the interaction between the two systems defined by the root definitions, organization and individual knowledge worker.

\section{Contemplation of the Interaction between the Systems}

To explore the interaction between the two systems defined by the root definitions the literature was revisited. This section discusses current research factions, the new perspective of the individual knowledge worker and then takes steps towards a holistic view of knowledge worker productivity.

\subsection{Current Research Factions—Knowledge Management or Retain and Invest in Knowledge Workers}

As mentioned in the introduction current research can mostly be split into two factions. One of those factions consists of those who believe that knowledge can be codified into external systems and that knowledge worker productivity can be improved through knowledge management. The other faction consists of those who do not believe that knowledge can be codified, so that the emphasis needs to be on retaining knowledge workers and investing in them. However, both factions mostly focus on knowledge not the knowledge worker himself. The perspective is that the knowledge is the resource while the knowledge worker is the package that contains it. You can either try to remove the resource from the package, as knowledge management attempts, or you can keep and manipulate the package to use the resource, by retaining and investing in the knowledge worker. Investing in the knowledge worker is just a means to an end.

The results of the literature review of academic papers showed these two factions in the identified challenges of information needs and knowledge interdependence and motivation, work engagement and health targeted by the academic papers. Knowledge management is a proposed solution to the challenge of information needs and knowledge interdependence. Knowledge management research covers a wide range of subjects pertaining to knowledge, such as knowledge transfer, creation, adoption, flow, sourcing and dissemination. It also covers information use behavior, such as search, extraction and information overload. Recently researching the benefits and problems of using technology like information systems and knowledge management systems as well as how to design these systems has been popular.

The main theme throughout knowledge management literature is that the organizational knowledge base gives the organization a competitive advantage and that organizations need to manage this organizational knowledge base. Knowledge workers need to contribute to this organizational knowledge base to be valuable to the organization. Therefore, to improve knowledge worker productivity the organization needs to devise of ways to increase the knowledge worker's contribution to the organizational knowledge base. They can do that through collaboration and knowledge sharing. Collaboration makes use of the knowledge of many to solve problems and get things done. Through collaboration knowledge is transferred from one worker to another and often new knowledge is acquired by all participants. Knowledge sharing can then be done by, for example, documenting knowledge into information systems or reports. Figure 3 shows a simplified view of the knowledge worker productivity problem from the perspective of knowledge management. 


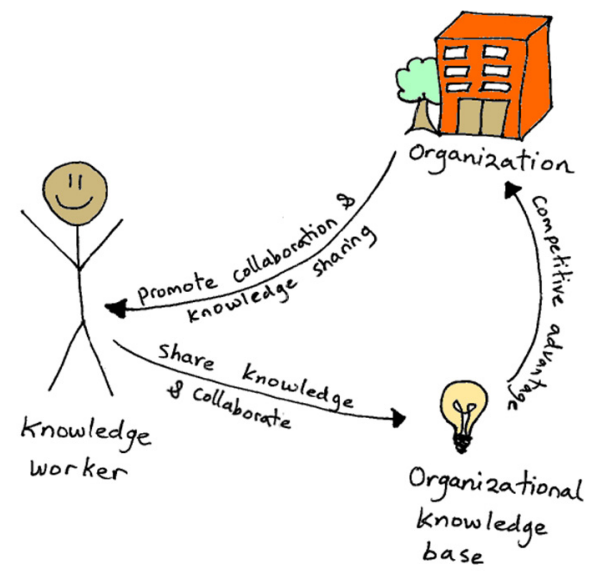

Figure 3. The knowledge worker productivity problem from the perspective of knowledge management.

Research on retaining and investing in knowledge workers propose solutions to the challenge of motivation, work engagement and health targeted by the academic papers in the literature review. If knowledge cannot be codified into external systems, organizations need to retain their knowledge workers and invest in them, to not lose organizational knowledge by turnover. Research in the faction of retaining and investing covers an even wider range of subjects than knowledge management, such as job satisfaction, worker behavior, stress, organizational commitment, psychological distress, social support, ergonomics and work identity. This faction believes that by fulfilling the needs of the knowledge worker his performance improves, giving the organization better access to his knowledge and increasing his commitment to the organization. If the knowledge worker's commitment is low he could leave the organization, taking his organizational knowledge with him. The main theme of this research is that the organization needs to fulfill the needs of the knowledge worker to increase performance and commitment to the organization. Figure 4 shows a simple view of the knowledge worker productivity problem from the perspective of retaining and investing in knowledge workers.

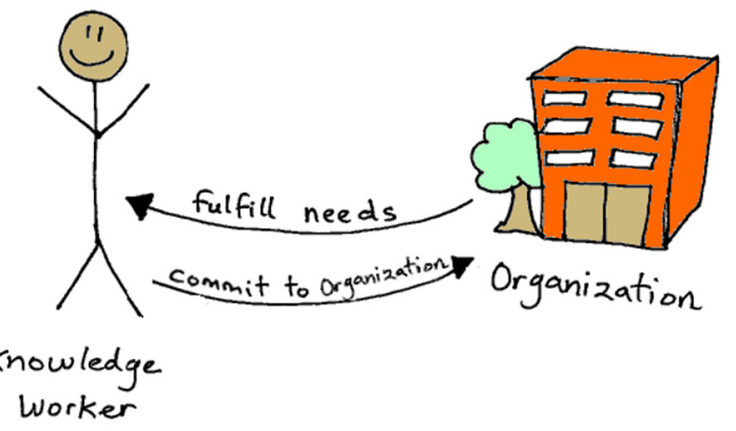

Figure 4. The knowledge worker productivity problem from the perspective of retaining and investing in knowledge workers.

When looking at these two factions from higher levels of abstraction, they do not oppose each other's theories but complement them. To solve the knowledge worker productivity challenge, the findings of these factions need to be combined into a holistic approach. There is a need to find a balance between codifying knowledge and investing in knowledge workers to increase their performance and commitment to improve knowledge worker productivity. There is one thing missing though in current research: the perspective of the individual knowledge worker. How does he fit into the knowledge worker productivity dilemma? The next section discusses insights that the perspective of the individual knowledge worker can give to the problem situation in the context of current research. 


\subsection{The Individual Knowledge Worker-A New Perspective}

Most of the current research read did not tackle the knowledge worker productivity challenge from the perspective of the individual knowledge worker. The individual knowledge worker is only explored from the perspective of the organization. The individual knowledge worker's experiences and perceptions of his own productivity are rarely explored. The eight main challenges identified in the literature review of the personal productivity self-help books highlighted important factors the individual knowledge worker needs to deal with daily which affect his productivity. For example, the challenge of self-awareness and self-development touches on everything the knowledge worker does. He needs self-awareness and self-development to be effective and efficient. The worker needs to be effective and efficient to deal with demands with the resources he has. The perspective of the individual knowledge worker gives a new dimension to the knowledge worker productivity dilemma.

Figure 3 showed a simple view of the knowledge worker productivity challenge from the perspective of knowledge management research. If the dimension of the individual knowledge worker is added to that figure, two important factors stand out which are often forgotten. Figure 5 shows the extended figure. The individual knowledge worker needs self-awareness and self-development to contribute to the organizational knowledge base. Self-awareness allows the worker to know what knowledge he has which needs to be shared and self-development is necessary for the worker to adopt new knowledge to enrich the organizational knowledge base. The other factor is relationships. The individual knowledge worker needs to create and develop relationships to have access to needed resources, the knowledge of others, and collaborate successfully.

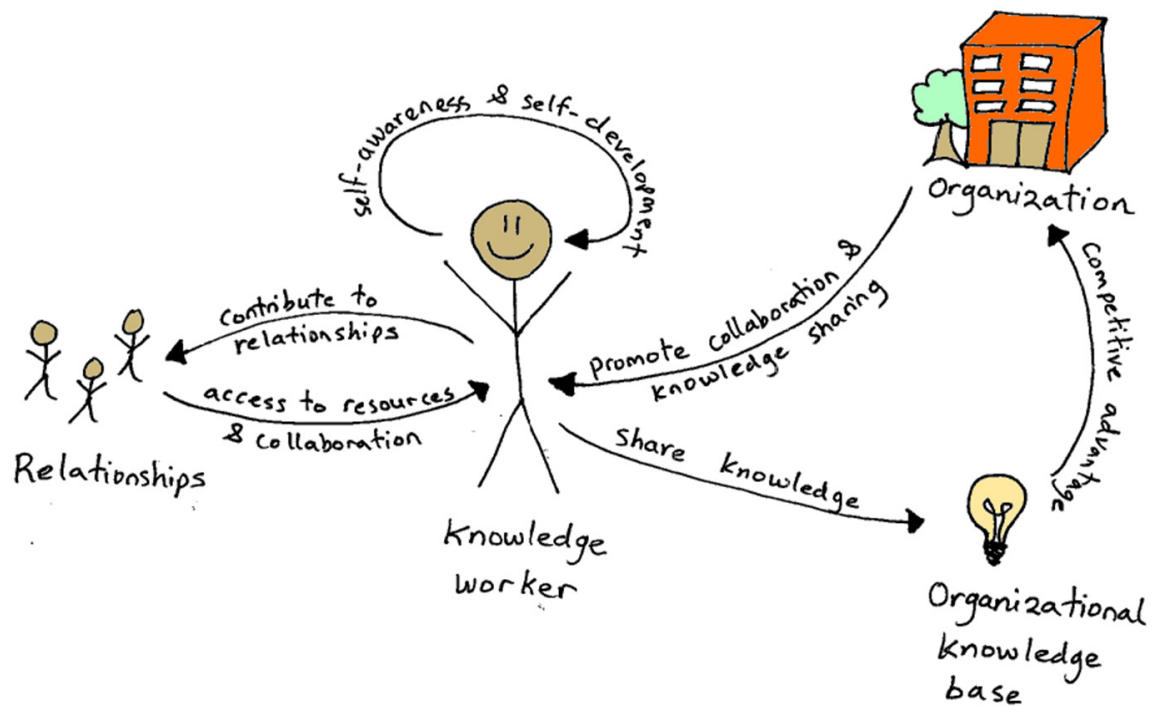

Figure 5. The knowledge worker productivity problem from the perspective of knowledge management including the individual knowledge worker.

The same can be done to the simple view of the knowledge worker productivity challenge from the perspective of retaining and investing in knowledge workers (see Figure 4). When the dimension of the individual knowledge worker is added to the figure, two important factors stand out as well. Figure 6 shows this extended figure. Self-awareness and self-development is again a factor. The knowledge worker needs self-awareness to identify his needs so that he can communicate them to the organization. If the knowledge worker communicates his needs, the organization can fulfill them more effectively. The other factor is personal resource management. The worker needs to manage his personal resources to perform to full potential. The worker also uses self-awareness and self-development to manage personal resources. This includes, for example, managing basic things like sleep, nutrition and exercise 
as well as more complex things like controlling emotions, living in alignment with principles and social interaction.

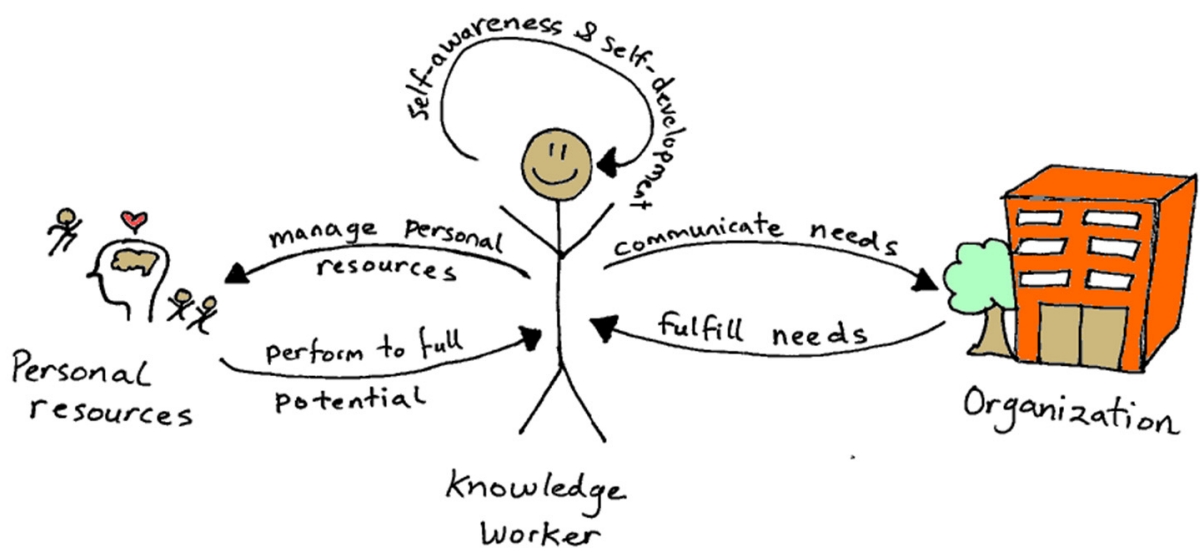

Figure 6. The knowledge worker productivity problem from the perspective of retaining and investing in knowledge workers including the individual knowledge worker.

The knowledge worker cannot just be a means to an end. The whole knowledge worker is the resource not just his knowledge. The individual knowledge worker needs to be proactive and take responsibility for his own productivity. The organization cannot control so many of the factors that influence his performance. The organization can only create the optimal work environment that supports the knowledge worker, helps him thrive and influences him to create value for the organization. However, the organization cannot do that if the knowledge worker does not know himself what he needs from his work environment and therefore cannot communicate his needs. The knowledge worker needs to manage his personal resources to perform to his full potential. If the knowledge worker does not manage his personal resources he is more susceptible to stress, exhaustion and burnout which leads to underperformance and creates a vicious cycle. This vicious cycle often ends with the employee leaving or being terminated.

The individual knowledge worker plays a significant role in a possible solution to the knowledge worker productivity challenge. There is a need to understand the individual knowledge worker and train him so that he can take responsibility for the factors only he has control over which affect his own productivity. Combining the two factions of current research and the dimension of the individual knowledge worker would be a first step towards a holistic view of knowledge worker productivity. This paper attempts this at a high level of abstraction. The next section discusses the resulting holistic view.

\subsection{Towards a Holistic View of Knowledge Worker Productivity}

The rich picture from the perspective of the organization highlighted three fundamental influencers of knowledge worker productivity. The organization must communicate what they perceive as value, the organization needs to promote collaboration and knowledge sharing and create a work environment where they motivate and fulfill the needs of their knowledge workers. Most research on knowledge worker productivity falls into one of these groups indicating a successful abstraction. This rich picture combines the fundamentals from the two factions of current research, knowledge management and retaining and investing in knowledge workers.

There is a clear thread running through current research that was visible when looking at the challenges targeted. That thread stems from changes connected to new information and communication technology, the nature of the knowledge worker and his job and the fact that modern organizations must rely on the knowledge of their workers for competitive advantage. Information and communication technology is facilitating the reorganization of bureaucratic structures, globalization, 
outsourcing, mobility of workers and cross-functional teams (Amidon and Blythe 2008). Routine nonconformity, mistakes, misconduct and disasters are systematic products of the complex structures and processes that many modern organizations have (Vaughan 1999). Organizations must reorder their functional priorities by shifting their focus from production and product development to creating the right environment for their knowledge workers (Hori 1993).

Martin (2013) says that organizations make the mistake of structuring their knowledge workforce as they do a manual workforce where each employee is doing the same tasks every day, which is counterintuitive to the nature of the knowledge worker and his job. Knowledge work comes primarily in the form of projects, not routine daily tasks that can result in downtime if the workforces are organized around permanent full-time jobs (Martin 2013). Knowledge worker jobs need to be flexible so the organization can redeploy resources where needed (Martin 2013). A flexible structure would reduce overhead costs and lessen the likelihood of ending up in the destructive cycle of hiring and firing (Martin 2013). However, when many of the conventional methods of managing the productivity of manual work are applied to knowledge workers, their productivity improves even though current research agrees that knowledge work is fundamentally different from manual work. This phenomenon needs to be explored. One hypothesis is that most workers do not solely work as knowledge workers; part of their job is manual and involves routine tasks. Therefore, the conventional methods of managing productivity of manual work improve the manual part of a knowledge worker's job. Drucker (1999) called these workers technologists.

The rich picture from the perspective of the individual knowledge worker highlighted the fact that knowledge workers need to manage their personal resources, be effective and efficient to maximize their own productivity. This rich picture shows the fundamentals of the dimension of the individual knowledge worker discussed earlier. The two systems, from the perspective of organizations and individual knowledge workers, differ in their boundaries. The organization has control over the work environment and needs to influence knowledge workers to transform effort into value while the individual knowledge worker has control over himself and needs to influence the environment to transform effort into value. These two systems are interdependent and should complement each other to give the best insight into what can be done to improve knowledge worker productivity.

Figure 7 shows on a high level of abstraction how these two systems interact. On the highest level of abstraction, knowledge worker productivity is dependent on the success of the basic interactions of the organization communicating what is perceived as value to them and the knowledge worker performing effective actions efficiently to create that value. Inside the box in Figure 7 the fundamental interactions needed for the knowledge worker to perform effective actions efficiently are highlighted. The knowledge worker needs self-awareness and self-development to identify his needs, personal resources and competences. He can only then communicate his needs to the organization, share knowledge to contribute to the organizational knowledge base and manage his personal resources and competences to perform to full potential. If the knowledge worker is performing to full potential, he is using his personal resources effectively and efficiently. The individual knowledge worker needs to work within the boundary of his work environment. The organization needs to create a work environment that fulfills the knowledge worker's needs, motivates him towards creating value for the organization and promotes collaboration and knowledge sharing. Knowledge workers are interdependent and have a need to feel connected to others. The knowledge worker needs to spend time and energy in contributing to relationships to gain access to resources, such as other worker's knowledge. Relationships also facilitate collaboration, by creating e.g., mutual experiences, trust and respect, and fulfill the need to feel connected to others. The knowledge worker is being effective when spending time in forming and developing the right relationships. This process often does not look like value creating work, for example, employees on a coffee break or playing a game during office hours. 


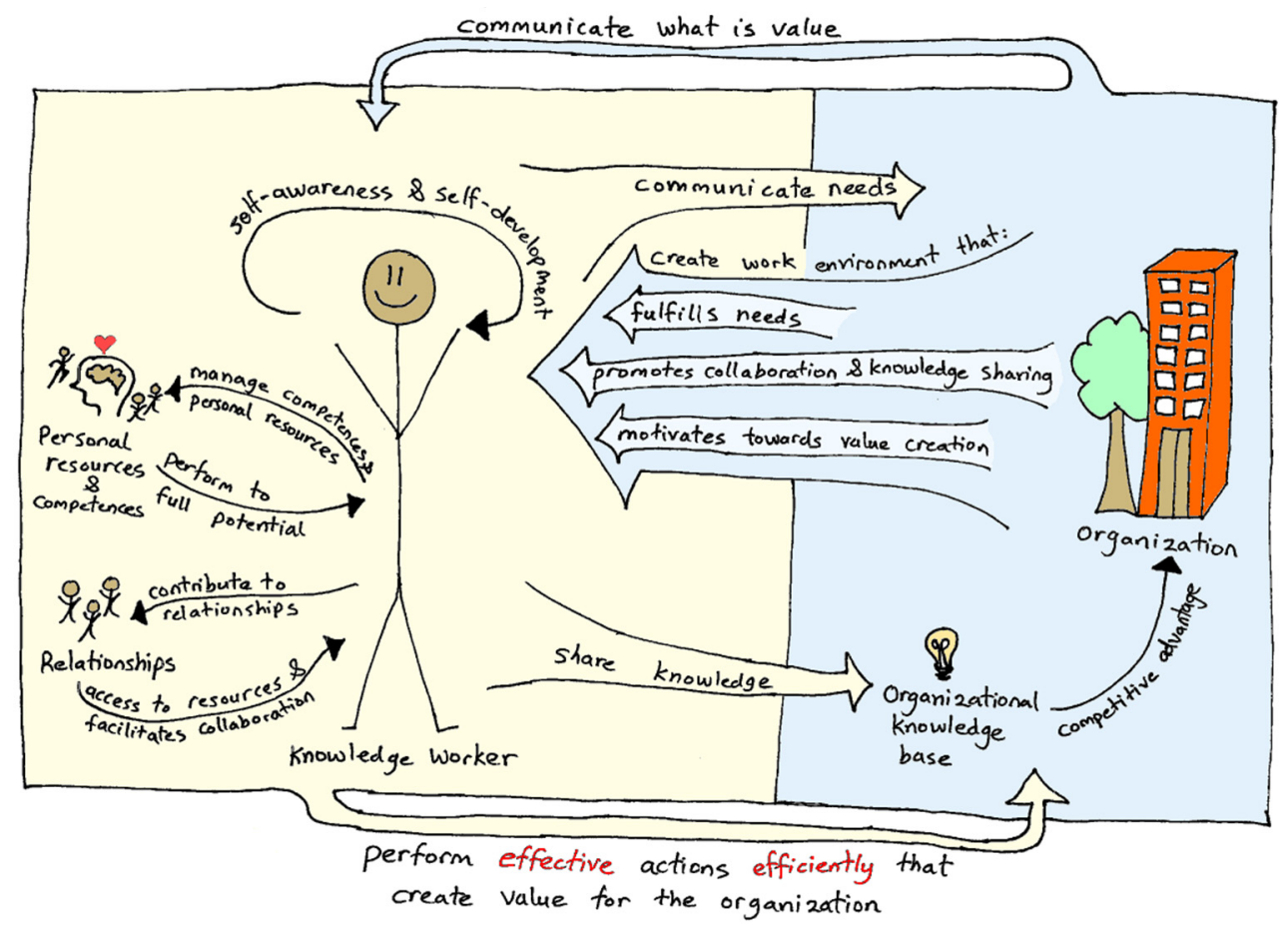

Figure 7. A simple holistic view of knowledge worker productivity.

This simple holistic view of knowledge worker productivity includes the fundamentals of the two factions of current research and the dimension of the individual knowledge worker identified in the literature reviews. The next section discusses recommendations for further research to get us closer to solving the knowledge worker productivity challenge.

\section{Discussions}

This research is a first step of many towards a holistic view of knowledge worker productivity. It focused on the abstraction of the problem situation into simple rich pictures and defining relevant systems. The simple rich pictures and root definitions are subjective interpretations of knowledge worker productivity based on inferences made in the two literature reviews. The perspectives of the researchers influenced the interpretations and inferences made throughout the process. This research only tackled the first three stages of the soft systems approach. The social and political system were not included and in the literature reviews restrictive search parameters were used which might have excluded some papers of possible significance.

There is a need to go back to the fundamental questions around knowledge worker productivity such as what are the characteristics of knowledge workers, how does knowledge work differ from manual work and how do the knowledge worker and organization interact? There is a lack of empirical studies that observe and analyze knowledge workers. Most initiatives that organizations take to improve knowledge worker productivity are a hit or miss depending on factors that are often hidden and unknown. The reason knowledge worker productivity has not been approached holistically very often is because of the perceived vastness of this problem. This vastness comes from the amount of and level of detail of current research. Therefore, the first step to a holistic approach is looking at the problem from the highest possible level of abstraction to identify the fundamentals of knowledge worker productivity. This paper presented such an abstraction from literature reviews of knowledge worker productivity challenges.

The next step in this research should be to take the results from the analysis of the problem situation and create conceptual models, using soft systems methodology. Conceptual models explore through logic what needs to be done to achieve the purpose conveyed in the root definitions. They 
give insight into possible intervention points to improve knowledge worker productivity and give ideas for research opportunities. Intervention points are where a change could be made to improve the real problem situation. By looking at the rich pictures possible intervention points could be in creating the work environment, managing personal resources and communication between organizations and their knowledge workers. These are factors that can have positive or negative effect on knowledge worker productivity depending on how they are tackled. The effect of changes at the intervention points can be explored by digging deeper into these intervention points and using other tools, such as causal loop diagrams and system models using system dynamics. Future research can contribute to the holistic view of knowledge worker productivity by, for example, doing literature reviews on intervention points, case research on parts of the conceptual model and action research on intervention points. It would also be beneficial if future research would complete the analyses, of the social system and political system, to explore their effect on the knowledge worker productivity system. The social system and political system probably play a large part in the hidden and unknown factors that make productivity initiatives a hit and miss. The final objective is to find applicable methods and tools to manage and improve knowledge worker productivity.

There is a treasure trove of information regarding knowledge worker productivity in academic and popular literature. There is a need to consolidate it to create a holistic view of knowledge worker productivity to aid in the revolution of the management of knowledge workers.

Author Contributions: Helga Guðrún Óskarsdóttir and Guðmundur Valur Oddsson conceived and designed the research; Helga Guðrún Óskarsdóttir performed the research, analyzed the data and wrote the paper.

Conflicts of Interest: The authors declare no conflict of interest.

\section{References}

Agumba, Justus Ngala, and Ferdinand Cedric Fester. 2010. Participation in formal mentoring programme in South African construction industry: A perspective of new knowledge workers. African Journal of Business Management 4(10): 1954-63.

Allen, David. 2001. Getting Things Done: How to Achieve Stress-Free Productivity. London: Piatkus Books Ltd.

Ambos, Tina C., and Bodo B. Schlegelmilch. 2009. Managing knowledge in International Consulting Firms. Journal of Knowledge Management 13(6): 491-508.

Amidon, Stevens, and Stuart Blythe. 2008. Wrestling with proteus-Tales of communication managers in a changing economy. Journal of Business and Technical Communication 22(1): 5-37. [CrossRef]

Babauta, Leo. 2008. Zen To Done. Charleston: CreateSpace.

Barjis, Joseph, Ashish Gupta, and Ramesh Sharda. 2011. Knowledge work and communication challenges in networked enterprises. Information Systems Frontiers 13(5): 615-19. [CrossRef]

Baumeister, Roy F., and John Tierney. 2011. Willpower: Rediscovering the Greatest Human Strength. New York: Penguin Books.

Bennington, Emily, and Skip Lineberg. 2010. Effective Immediately. Berekely: Ten Speed Press.

Blanchard, Ken, Susan Fowler, and Laurence Hawkins. 2005. Self Leadership and the One Minute Manager. London: Harper Collins.

Bullen, Christine V. 1995. Reexamining Productivity Csfs-The Knowledge Worker Challenge. Information Systems Management 12(3): 13-18.

Chandler, Steve. 2011. Time Warrior. Richmond: Maurice Bassett.

Chatti, Mohamed Amine. 2012. Knowledge management: A personal knowledge network perspective. Journal of Knowledge Management 16(5): 829-44. [CrossRef]

Checkland, Peter. 1993. Systems Thinking, Systems Practice. England: John Wiley \& Sons Ltd.

Checkland, Peter, and Jim Scholes. 1990. Soft Systems Methodology in Action. England: John Wiley \& Sons Ltd.

Checkland, Peter, and Jim Scholes. 1999. Soft Systems Methodology in Action. England: John Wiley \& Sons Ltd.

Cheng, Yi-Chia, and Hsin-Te Yeh. 2009. From concepts of motivation to its application in instructional design: reconsidering motivation from an instructional design perspective. British Journal of Educational Technology 40(4): 597-605. [CrossRef] 
Covey, Stephen R. 2004. The 7 Habits of Highly Effective People, 15th Anniversary Edition ed. London: Simon \& Schuster UK Ltd.

Covey, Stephen R., A. Roger Merrill, and Rebecca R. Merrill. 1994. First Things First: Coping with the Ever-Increasing Demands of the Workplace. London: Simon \& Schuster UK Ltd.

Darr, Asaf, and Chris Warhurst. 2008. Assumptions, assertions and the need for evidence - Debugging debates about knowledge workers. Current Sociology 56(1): 25-45. [CrossRef]

De Bono, Edward. 2000. Six Thinking Hats: Revised and Updated. London: Penguin Books.

Deci, Edward L. 1995. Why We Do What We Do. Harmondsworth: Penguin Books.

Delbridge, Rick, James Lowe, and Nick Oliver. 2000. Shopfloor responsibilities under lean teamworking. Human Relations 53(11): 1459-79. [CrossRef]

Devilliers, A.M. 1980. Understanding White-Collar Productivity-How To Solve The Problem. Journal of Micrographics 13(6): 43-46.

Ditton, Mary J. 2009. How social relationships influence academic health in the 'enterprise university': An insight into productivity of knowledge workers. Higher Education Research $\mathcal{E}$ Development 28(2): 151-64.

Drucker, Peter F. 1959. The Landmarks of Tomorrow. New York: Harper \& Brothers.

Drucker, Peter F. 1966. The Effective Executive. New York: Harper \& Row.

Drucker, Peter F. 1999. Knowledge-worker productivity: The biggest challenge. California Management Review 41: 79-94. [CrossRef]

Duguid, Paul. 2006. What Talking about Machines tells us. Organization Studies 27(12): 1794-804. [CrossRef]

Duhigg, Charles. 2012. The Power of Habit: Why We Do What We Do and How to Change. London: Random House.

Dylag, Anna, Magdalena Jaworek, Waldemar Karwowski, Małgorzata Kożusznik, and Tadeusz Marek. 2013. Discrepancy between individual and organizational values: Occupational burnout and work engagement among white-collar workers. International Journal of Industrial Ergonomics 43(3): 225-31. [CrossRef]

Gambardella, Alfonso, Claudio Panico, and Giovanni Valentini. 2015. Strategic Incentives To Human Capital. Strategic Management Journal 36(1): 37-52. [CrossRef]

Garrick, John, and Stewart Clegg. 2001. Stressed-out knowledge workers in performative times: A postmodern take on project-based learning. Management Learning 32(1): 119-34. [CrossRef]

Gleadle, Pauline, Damian Hodgson, and John Storey. 2012. 'The ground beneath my feet': projects, project management and the intensified control of R\&D engineers. New Technology Work and Employment 27(3): 163-77.

Gleeson, Kerry. 2009. The Personal Efficiency Program, 4th ed. New York: John Wiley \& Sons, Inc.

Goleman, Daniel. 1999. Working with Emotional Intelligence. London: Bloomsbury Publishing Plc.

Greenblatt, Edy. 2009. Restore Yourself: The Antidote for Professional Exhaustion. Los Angeles: Execu-Care Press.

Gunasekaran, A., A.R. Korukonda, I. Virtanen, and P. Yli-Olli. 1994. Improving Productivity And Quality In Manufacturing Organizations. International Journal of Production Economics 36(2): 169-83. [CrossRef]

Harvard Business Essentials. 2005. Time Management: Increase Your Personal Productivity and Effectiveness. Watertoen: Harvard Business School Publishing Corporation.

Hasan, Helen, and Charmaine C. Pfaff. 2012. An Activity-Theory Analysis of Corporate Wikis. Information Technology \& People 25(4): 423-37.

Henry, Todd. 2011. The Accidental Creative: How to Be Brilliant at a Moment's Notice. New York: Portfolio Penguin.

Holden, Lorne. 2012. Make It Happen in 10 Minutes a Day. New England: Holden.

Hori, S. 1993. Fixing Japan White-Collar Economy-A Personal View. Harvard Business Review 71(6): 157-72.

Hubbard, Elbert. 2011. A Message To Garcia Being A Preachment. Charleston: CreateSpace.

Hwang, Jin-Sook, and Hee-Ja Yoo. 2012. The relationships among job characteristics, organizational commitment, and job satisfaction of fashion industry professionals. Journal of Korea Design Forum 37: 131-42.

Jayasingam, Sharmila, and Jing Ren Yong. 2013. Affective commitment among knowledge workers: the role of pay satisfaction and organization career management. International Journal of Human Resource Management 24(20): 3903-20. [CrossRef]

Jayasingam, Sharmila, Muhiniswari Govindasamy, and Sharan Kaur Garib Singh. 2016. Instilling affective commitment: insights on what makes knowledge workers want to stay. Management Research Review 39(3): 266-88. [CrossRef]

Jung, Mee-Sook. 2008. Application of TRIZ to Enhance Problem Solving Competence for Secretaries. Journal of Secretarial Sciences 17(2): 73-97. 
Kalman, Yoram M., and Gilad Ravid. 2015. Filing, piling, and everything in between: The dynamics of E-mail inbox management. Journal of the Association for Information Science and Technology 66(12): 2540-52. [CrossRef]

Ke, Chih-Kun, and Duen-Ren Liu. 2011. Context-Based Knowledge Support For Problem-Solving By Rule-Inference And Case-Based Reasoning. International Journal of Innovative Computing Information and Control (7A): 3615-31.

Kelley, Robert E. 1998a. How to Be a Star at Work: Nine Breakthrough Stategies You Need to Succeed. New York: Three Rivers Press.

Kelley, Robert E. 1998b. How to Manage Your Work Life (and Become a Star). Training E Development 52(5): 56+.

Keneley, Monica J. 2008. Monitoring and motivating outworkers: the case of the AMP and the sale of industrial life insurance 1905-1940. Labor History 49(3): 319-40. [CrossRef]

Kitchenham, B. 2004. Procedures for Performing Systematic Reviews. Keele: Keele University.

Koch, Richard. 2008. The 80/20 Principle: The Secret of Achieving More with Less. New York: Random House, Inc.

Kwon, S., J. Park, and J. Park. 2014. A Study on the Rational Regulation of Working Hours: From the Perspective of White-Collar Workers. Journal of CEO and Management Studies 17(4): 257-89.

Lai, Chin-Hui. 2015. Applying Knowledge Flow Mining to Group Recommendation Methods for Task-Based Groups. Journal of the Association for Information Science and Technology 66(3): 545-63. [CrossRef]

Leland, Karen, and Keith Bailey. 2008. Time Management in an Instant. USA: Career Press.

Letiche, Hugo, and René van Hattem. 2000. Self and organization-Knowledge work and fragmentation. Journal of Organizational Change Management 13(4): 352-74. [CrossRef]

Lewis, Allyson. 2012. The 7 Minute Solution. New York: Simon \& Schuster.

Li, Sheng-Tun, and Won-Chen Chang. 2009. Exploiting and transferring presentational knowledge assets in R\&D organizations. Expert Systems with Applications 36(1): 766-77.

Liu, Duen-Ren, and Chih-Kun Ke. 2007. Knowledge support for problem-solving in a production process: A hybrid of knowledge discovery and case-based reasoning. Expert Systems with Applications 33(1): 147-61. [CrossRef]

Liu, Duen-Ren, Chin-Hui Lai, and Ya-Ting Chen. 2012. Document recommendations based on knowledge flows: A hybrid of personalized and group-based approaches. Journal of the American Society for Information Science and Technology 63(10): 2100-17. [CrossRef]

Loehr, Jim, and Tony Schwartz. 2003. The Power of Full Engagement: Managing Energy, Not Time, Is the Key to High Performance and Personal Renewal. New York: Free Press.

Makinen, Sari. 2012. Mobile work and its challenges to personal and collective information management. Information Research-an International Electronic Journal 17(3): 2.

Mandt, Edward. 1978. Managing Knowledge Worker Of Future. Personnel Journal 57(3): 138-43.

Manville, Brook, and Josiah Obe. 2003. Beyond empowerment: Building a company of citizens. Harvard Business Review 81(1): 48-53.

Martin, Roger L. 2013. Rethinking the Decision Factory. Harvard Business Review 91(10): 96-104.

Maxwell, John C. 2009. How Successful People Think. New York: Center Street.

Meadows, Donella H. 2008. Thinking in Systems: A Primer. White River Junction: Chelsea Green Publishing.

Meier, J.D. 2010. Getting Results the Agile Way. Bellevue: Innovation Playhouse LLC.

Moran, Brian P., and Michael Lennington. 2013. The 12 Week Year: Get More Done in 12 Weeks Than Others Do in 12 Months. New York: John Wiley \& Sons, Inc.

Mudambi, Ram, Susan M. Mudambi, and Pietro Navarra. 2007. Global innovation in MNCs: The effects of subsidiary self-determination and teamwork*. Journal of Product Innovation Management 24(5): 442-55. [CrossRef]

Muller-Smith, P. 1997. Like herding cats. Journal of Perianesthesia Nursing 12(6): 439-41. [CrossRef]

Óskarsdóttir, Helga Guðrún. 2013. reviewSearchHelper. Available online: https://github.com/helgagu/ reviewSearchHelper (accessed on 20 July 2017).

Óskarsdóttir, Helga Guðrún. 2014. A Mapping of an Agile Software Development Method to the Personal Productivity of the Knowledge Worker. A Systematic Review of Self-Help Books. In Faculty of Industrial Eng., Mechanical Eng. and Computer Science. Reykjavík: University of Iceland.

Pash, Adam, and Gina Trapani. 2011. Lifehacker, 3 ed. Indianapolis: Wiley Publishing.

Paton, Steve. 2013. Introducing Taylor to the knowledge economy. Employee Relations 35(1): 20-38. [CrossRef] 
Paul, Richard, and Linda Elder. 2013. Critical Thinking: Tools for Taking Charge of Your Professional and Personal Life. Upper Saddle River: Pearson Education, Inc.

Perry, John. 2012. The Art of Procrastination. New York: Workman Publishing Company, Inc.

Richardson, Peter, and James Larsen. 1997. Repetitive strain injuries in the information age workplace. Human Resource Management 36(4): 377-84. [CrossRef]

Scarbrough, Harry. 1999. Knowledge as work: Conflicts in the management of knowledge workers. Technology Analysis \& Strategic Management 11(1): 5-16.

Schwartz, Tony, Jean Gomes, and Catherine McCarthy. 2010. Be Excellent at Anything: Four Keys to Transforming the Way We Work and Live. New York: Free Press.

Scott, Steven K. 2004. Mentored by a Millionaire. Hoboken: John Wiley \& Sons.

Seethamraju, Ravi. 2000. Knowledge management issues in the management of professional engineers. Journal of Scientific $\mathcal{E}$ Industrial Research 59(8-9): 710-19.

Selk, Jason. 2009. 10-Minute Toughness. New York: McGraw-Hill.

Shao, Benjamin, Peng-Yeng Yin, and Andrew Chen. 2014. Organizing knowledge workforce for specified iterative software development tasks. Decision Support Systems 59: 15-27. [CrossRef]

Song, Mike, Vicki Halsey, and Tim Burress. 2007. The Hamster Revolution. San Francisco: Berrett-Koehler Publishers. Stack, Laura. 2004. Leave the Office Earlier. New York: Broadway Books.

Stanier, Michael Bungay. 2010. Do More Great Work. New York: Workman Publishing Company, Inc.

Stanton, Erwin S. 1972. White Collar Unionization-New Challenge To Management. Personnel Journal 51(2): 118-29.

Tan, Chade-Meng. 2012. Search Inside Yourself. London: Collins.

Tangen, Stefan. 2005. Demystifying productivity and performance. International Journal of Productivity and Performance Management 54(1): 34-46. [CrossRef]

Taylor, Frederick Winslow. 1911. The Principles of Scientific Management. New York and London: Harper \& Brothers Publishers.

Tracy, Brian. 2013. Eat That Frog: Get More of the Important Things Done Today, 2nd ed. London: Hodder \& Stoughton Ltd.

Ulbrich, Armin, Dolly Kandpal, and Klaus Tochtermann. 2014. Dynamic personalization in knowledge-based systems from a structural viewpoint. In Metainformatics: International symposium, mis 2003, graz, austria, september 17-20, 2003. Revised papers; Edited by David L. Hicks. Berlin, Heidelberg: Springer Berlin Heidelberg, pp. 126-42.

Van der Heijden, Gielis A. H., Jeroen Schepers, and Edwin J. Nijssen. 2012. Understanding workplace boredom among white collar employees: Temporary reactions and individual differences. European Journal of Work and Organizational Psychology 21(3): 349-75. [CrossRef]

Vanderkam, Laura. 2010. 168 Hours: You Have More Time than You Think. New York: Portfolio Penguin.

Vaughan, Diane. 1999. The dark side of organizations: Mistake, misconduct, and disaster. Annual Review of Sociology 25: 271-305. [CrossRef]

(c) 2017 by the authors. Licensee MDPI, Basel, Switzerland. This article is an open access article distributed under the terms and conditions of the Creative Commons Attribution (CC BY) license (http:/ / creativecommons.org/licenses/by/4.0/). 